\title{
Dampak InstruksI BupatI Tentang Zakat ProfesI \\ Terhadap Pegawal dan Pengelolaan Zakat DI Bazis Kabupaten Bogor*
}

\author{
(THE IMPACT OF THE REGENT INSTRUCTIONS ABOUT ZAKAT \\ PROFESSION AGAINST EMPLOYEES AND MANAGEMENT OF ZAKAT IN \\ BAZIS BOGOR REGENCY)
}

\author{
Muhammad Jimmy Kurniawan \& Ahmad Sobari \\ FAI Universitas Ibn Khaldun Bogor \\ Jl. KH. Sholeh Iskandar Bogor \\ E-mail: jimmy_kurniawan@yahoo.com
}

\begin{abstract}
Zakat is worship maaliyah ijtima'iyah which has a very important position, strategic, and decisive, both in terms of Islam and of the welfare of the development side. As a subject of worship, charity, including one of the pillars (the third pillar) of the five pillars of Islam, as expressed in various hadith of the Prophet, so its presence is considered as Ma'lum minad-deen bidharuurah or their recognized automatically and an essential part of the Islamic someone.
\end{abstract}

Keywords: Zakat Profession, Bupati Instruction, Bazis

\begin{abstract}
Abstrak: Zakat adalah ibadah maaliyah ijtima'iyah yang memiliki posisi sangat penting, strategis, dan menentukan, baik dilihat dari sisi ajaran Islam maupun dari sisi pembangunan kesejahteraan umat. Sebagai suatu ibadah pokok, zakat termasuk salah satu rukun (rukun ketiga) dari rukun Islam yang lima, sebagaimana diungkapkan dalam berbagai hadits Nabi, sehingga keberadaannya dianggap sebagai ma'lum minad-diin bidharuurah atau diketahui secara otomatis adanya dan merupakan bagian mutlak dari keislaman seseorang.
\end{abstract}

Kata Kunci: Zakat Profesi, Instruksi Bupati, Bazis

* Diterima tanggal naskah diterima: 24 Juli 2013, direvisi: 28 September 2013, disetujui untuk terbit: 23 November 2013. 


\section{Pendahuluan}

Di dalam Alquran terdapat dua puluh tujuh ayat yang menyejajarkan kewajiban shalat dengan kewaiban zakat dalam berbagai bentuk kata. ${ }^{1} \mathrm{Di}$ dalam Alqur'an terdapat pula berbagai ayat yang memuji orang yang bersungguh-sungguh menunaikannya, dan sebaliknya memberi ancaman bagi orang yang sengaja meninggalkannya. Sebagaimana khalifah Abu Bakar ash-Shidiq bertekad memerangi orang-orang yang tidak mau mengeluarkan zakat. Ketegasan sikap ini menunjukkan bahwa perbuatan meninggalkan zakat adalah suatu kedurhakaan dan jika hal ini dibiarkan, maka akan memunculkan berbagai kedurhakaan dan kemaksiatan lain. ${ }^{2}$

Oleh karena itu, ketika Rasulullah Saw. meninggal, banyak terjadi penolakan dari kaum munafiqin untuk membayar zakat. Mereka tidak mau berzakat meskipun mereka shalat. Kemudian Abu Bakar ash-Shiddiq secara tegas mengancam mereka dengan pernyataan beliau yang sangat terkenal, yang diriwayatkan oleh imam Abu Dawud:

“Demi Allah! Saya akan memerangi orang yang memisahkan kewajiban shalat dengan kewajiban zakat. Sesungguhnya zakat itu hak yang terkait dengan harta. Demi Allah! Jika mereka menolak mengeluarkan zakat unta yang biasa mereka tunaikan kepada Rasulullah Saw., pasti akau akan memerainginya, karena penolakan tersebut." (HR. Abu Dawud). ${ }^{3}$

Dari hadist diatas dapat kita ketahui bahwa shalat dan zakat itu memang dua hal yang tidak bisa dipisahkan. Dalam riwayat lain, Ibn Mas'ud menyatakan:

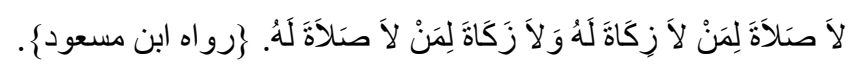

"Tidak dikatakan (tidak sah) shalatnya, orang yang tidak mau mengeluarkan zakat; dan tidak dikatakan berzakat, orang yang tidak melaksanakan shalat."

(HR. Ibn Mas'ud).

Jadi zakat itu, kalau boleh kita katakan, sesungguhnya adalah rukun Islam yang menekankan pada keshalehan sosial. Artinya, orang yang berzakat

\footnotetext{
${ }^{1}$ Yusuf al-Qardhawi, Fighuz Zakat,Muasasah Risalah Beirut,1991, hlm. 42.

${ }^{2}$ Hafidhuddin, Didin, Zakat Dalam Perekonomian Modern, Gema Insani, Jakarta, 2002, hlm. 2.

${ }^{3}$ Muhyiddin, 'Abdul Hamid Muhammad, Sunan Abu Daud, Maktabah Dahlan, hlm.93 kitab zakat.
} 
dengan baik, dengan ikhlas, insya Allah dia akan menjadi orang yang shaleh secara pribadi, dan juga shaleh secara sosial. ${ }^{4}$

Pembayaran zakat yang hanya sebatas melepaskan kewajiban, bisa berdampak pada pelestarian kemiskinan. Sebab, muzakki tidak mau tahu ke mana penggunaan dana zakat tersebut, apalagi mengontrol atau berupaya mendorong mustahik memanfaatkan dana zakat itu sebagai modal untuk merubah nasib, kareana zakat juga bisa dijadikan modal usaha, dagang atau membuat industry sekelompok mustahik agar terbebas dari jerat kemiskinan. ${ }^{5}$

Menurut Yusuf Qardhawi, ada beberapa cara penaggulangan kemiskinan. Pertama adalah dengan bekerja. Jadi, dana zakat yang dijadikan suatu modal untuk menciptakan industry maka akan bisa menampung beberapa mustahik untuk bekerja. Kedua adalah jaminan sanak family. Ketiga adalah jaminan Negara. Dan cara keempat dalam penaggulangi kemiskinan adalah melalui zakat. ${ }^{6}$

Maka oleh sebab itu sangat pentingnya para muzakki memainkan peranannya untuk mengeluarkan zakat, sehingga zakatnya bisa memberantas kemiskinan yang sudah banyak melanda Negara-negara maju. Dalam Al Qur'an Allah sangat melaknat orang yang mampu secara materi tapi tidak mau mengeluarkan zakat sehingga ia bisa dicap sebagai orang yang kafir. Dalam surat fushilat Allah Swt berfirman :

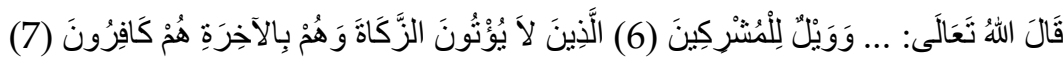

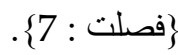

“... Dan kecelakaan besarlah bagi orang-orang yang mempersekutukan-Nya. (yaitu) orang-orang yang tidak menunaikan zakat dan mereka kafir akan adanya (kehidupan) akhirat." (QS. Fushilat: 6-7).

Jadi, ayat ini mengingatkan kepada kita, akan penting berzakat; sampai-sampai Allah SWT mengungkapkan masalah zakat ini dalam bentuk penyadaran, dengan tujuan agar manusia tidak menjadi budak materi, dan mau dikendalikan oleh materi, akan tetapi kemauan kita adalah dikendalikan oleh Allah SWT, dan dia diperintahkan untuk mengorbankannya, yakni

\footnotetext{
${ }^{4}$ Hafidhuddin, Didin, Rekaman Tentang Zakat, Risalah Zakat, Jakarta, 2006, h. 2.

${ }^{5}$ Juwaini, Ahmad, Membangun Peradapan Zakat, Institut Manajemen Zakat, Jakarta 2007 h. 5

6 Hafidhuddin, Didin, Panduan Praktis Tentang Zakat Infak Sedekah, Gema Insani, Jakarta, 1998, h. 1.
} 
dengan cara mengeluarkan sebagai harta yang dimilikinya. Hal ini sebagaimana tercantum dalam QS. At-Taubah ayat 103.

Jadi, zakat itu sebenarnya sangat luar biasa manfaatnya. Pantas bila masalah zakat ini banyak diungkapkan dalam ayat-ayat Alquran. Akan tetapi, sesungguhnya yang diungkapkan bukan hanya sekedar masalah zakat saja, melainkan juga masalah infaq dan shadaqah. Oleh karena itu, harus kita sadari, bahwa hal itu semua merupakan ciri bagi orang-orang yang beriman, yang disebut dalam ayat tersebut dengan sebenar-benarnya orang yang beriman. Sebagaimana firman-Nya pada QS. Al-Anfal ayat 2-4.

Ciri seseorang dikatakan sebagai mukmin yang sejati, adalah orang yang apabila disebut nama Allah, maka bergetarlah hatinya. Dia memiliki respon positif ketika nama Allah disebut, hukum-hukum Allah disebut; kalau dibacakan ayat-ayat Allah, baik ayat yang bersifat tanziliyyah (Alquran) maupun yang besifat kauniyyah (alam semesta), maka semakin bertambah imannya; bertawakkal kepada Allah SWT; mengerjakan shalat dengan baik; dan menginfakkan sebagian dari hartanya. ${ }^{7}$

Zakat juga sesungguhnya, dapat diistilahkan sebagai jaminan sosial, yakni jaminan sosial bagi masyarakat yang membutuhkan, orang-orang yang tidak mampu untuk bekerja, orang tua yang sudah jompo; tentu mereka berhak untuk mendapatkan dana dari zakat. Dan statusnya, mereka dapat disebut sebagai orang yang fakir atau bisa juga disebut sebagai orang yang miskin. Dan dana zakat yang diberikan kepada mereka, bertujuan untuk dapat digunakan dalam memenuhi kebutuhan sehari-harinya, karena mereka tidak mampu untuk bekerja.

Dapat dibayangkan, kalau orang-orang kaya mau memperhatikan mereka, tentu perbuatn itu sangatlah luar biasa di sisi Allah SWT. Oleh karena itu, orang yang suka memberi dikatakan sebagai sakhiey (dermawan) atau orang yang pemurah. Hal ini sebagaimana diungkapkan oleh Rasulullah Saw. dalam sabdanya, yang diriwayatkan oleh Imam Tirmdzi:

"Rasulullah Saw. bersabda: "Orang yang pemurah itu dekat dengan Allah, dekat dengan manusia, dekat dengan syurga, dan jauh dari neraka. Dan orang yang bakhil itu jauh dari Allah, jauh dari manusia, jauh dari syurga, dan dekat dengan neraka. Orang yang jahil (bodoh) tapi pemurah, itu lebih dicintai Allah daripada ahli ibadah tapi bakhil". (HR. Turmudzi). 8

${ }^{7}$ Hafidhuddin, Didin, Rekaman Tentang Zakat, Risalah Zakat, Jakarta, 2006, h. 3.

${ }^{8}$ Hafidhuddin, Didin, Rekaman Tentang Zakat, Risalah Zakat, Jakarta, 2006, h.5. 
Sayyid Quthub (w. 1965 M) dalam tafsirnya "Fi Dzilali Alquran" ketika menafsirkan firman Allah dalam surat al-Baqarah ayat 267 menyatakan, bahwa nash ini mencakup seluruh hasil usaha manusia yang baik dan halal dan mencakup pula seluruh yang dikeluarkan Allah SWT dari dalam dan atas bumi, seperti hasil-hasil pertanian, maupun hasil pertambangan seperti minyak. Karena itu, nash ini mencakup semua harta, baik yang terdapat di zaman Rasulullah Saw. maupun di zaman sesudahnya. Semuanya wajib dikeluarkan zakatnya dengan ketentuan dan kadar sebagaimana diterangkan dalam sunnah Rasulullah Saw. baik yang sudah diketahui secara langsung maupun yang di-qiyas-kan kepadanya. Al-Qurthubi (w. $671 \mathrm{H})$ dalam Tafsir al-Jaami' li Ahkam Alquran, menyatakan bahwa yang dimaksud dengan kata"حقِّ مَعُلُوم" (hak yang pasti) pada Alquran surat Adz-Dzariyat ayat 19 adalah zakat yang diwajibkan, artinya semua harta yang dimiliki dan semua penghasilan yang didapatkan, jika telah memenuhi persyaratan kewajiban zakat, maka harus dikeluarkan zakatnya. Dalam pasal 11 ayat (2) Bab IV Undang-undang No. 38/1999 tentang Pengelolaan Zakat, dikemukakan bahwa harta yang dikenai zakat adalah: a) emas, perak, dan uang; b) perdagangan dan perusahaan; c) hasil pertanian, hasil perkebunan, dan hasil perikanan; d) hasil pertambangan; e) hasil peternakan; f) hasil pendapatan dan jasa; dan g) rikaz. ${ }^{9}$

Berdasarkan uraian tersebut di atas, maka setiap keahlian dan pekerjaan apapun yang halal, baik yang dilakukan sendiri maupun yang terkait dengan pihak lain, seperti seorang pegawai atau karyawan, apabila penghasilan dan pendapatannya telah mencapai nishab, maka wajib dikeluarkan zakatnya.

Yusuf al-Qardhawi menyatakan bahwa diantara hal yang sangat penting untuk mendapatkan perhatian kaum muslimin saat ini adalah penghasilan atau pendapatan yang diusahakan melalui keahliannya, baik keahlian yang dilakukannya secara sendiri maupun secara bersama-sama. Yang dilakukan sendiri, misalnya profesi dokter, arsitek, ahli hukum, penjahit, pelukis, mungkin juga da'i atau muballigh, dan lain sebagainya. Yang dilakukan secara bersama-sama, misalnya pegawai (pemerintah maupun swasta) dengan menggunakan sistem upah atau gaji. Wahbah azZuhaili secara khusus mengemukakan kegiatan penghasilan atau pendapatan yang diterima seseorang melalui usaha sendiri (wirausaha) seperti dokter,

${ }^{9}$ Idem h.7 
insinyur, ahli hukum, penjahit dan lain sebagainya. Dan juga yang terkait dengan pemerintah (pegawai negeri) atau pegawai swasta yang mendapatkan gaji atau upah dalam waktu yang relatif tetap, seperti sebulan sekali. Penghasilan atau pendapatan yang semacam ini dalam istilah figh dikatakan sebagai al-Mall al-Mustafad. Sementara itu, fatwa ulama yang dihasilkan pada waktu Muktamar Internasional Pertama tentang Zakat di Kuwait pada tanggal 29 Rajab $1404 \mathrm{H}$ yang bertepatan dengan tanggal 30 April 1984 M, bahwa salah satu kegiatan yang menghasilkan kekuatan bagi manusia sekarang adalah kegiatan profesi yang menghasilkan amal yang bermanfaat, baik yang dilakukan sendiri, seperti kegiatan dokter, arsitek dan yang lainnya, maupun yang dilakukan secara bersama-sama, seperti para karyawan atau para pegawai. Semua itu menghasilkan pendapatan atau gaji. Mereka juga sepakat tentang wajibnya zakat profesi apabila telah mencapai nishab, meskipun mereka berbeda pendapat dalam cara mengeluarkannya. ${ }^{10}$

Majelis Ulama Indonesia (MUI) dalam fatwanya pada tanggal 06 Rabiul Akhir 1423 H/07 Juni 2002 M, menetapkan bahwa: “Setiap penghasilan atau pendapatan seperti gaji, honorarium, upah, jasa dan lain-lain yang diperoleh dengan cara halal, baik yang rutin maupun tidak rutin seperti dokter, pengacara, konsultan dan sejenisnya, serta pendapatan yang diperoleh dari pekerjaan bebas lainnya, wajib dikeluarkan zakatnya apabila telah memenuhi persyaratan kewajiban zakat". ${ }^{11}$

Dari kajian fiqih, timbul pertanyaan bagaimana menempatkan beragam komoditi dan jasa yang terus berkembang dari masa ke masa sebagai sumber atau objek zakat, termasuk yang berkaitan dengan nishab, besarnya zakat, waktu pengeluarannya, dan hal-hal lain yang berkaitan dengannya, terutama juga yang berkaitan dengan perkembangan ekonomi modern. ${ }^{12}$ Begitu pula hubungan zakat (muzakki) dengan lembaga pengelolaan zakat yang ada di tengah-tengah masyarakat yang dikelola oleh pemerintah maupun yang dikelola oleh masyarakat itu sendiri. Misalnya Badan Amil Zakat Infak dan Shadaqoh (BAZIS) yang berada di lingkungan pemerintah Kabupaten Bogor yang bertugas dalam mengelola dana zakat yang ada ditengah-tengah masyarakat dalam mensosialisasikannya, menghimpun dan mendistribusikannya kepada yang berhak menerima zakat. Masalah ini

\footnotetext{
${ }^{10}$ Idem h. 8

${ }^{11}$ Idris, Sofwan, Telaah Khusus Zakat Profesi, Risalah Zakat, Jakarta, 2006, h. 7.

12 Hafidhuddin, Didin, Zakat Dalam Perekonomian Modern, Gema Insani, Jakarta, 2002, h.
}

5. 
menarik dikaji secara mendalam, karena itulah skripsi ini disusun. Demikian pula hal-hal yang berkaitan dengan hikmah dan tujuan zakat diungkapkan kembali dalam skripsi ini dengan konprehensif.

Dengan memperhatikan semua latar belakang diatas, penulis ingin memberikan penjelasan kembali kepada masyarakat mengenai zakat dan segala persoalan didalamnya. Khususnya dalam hal zakat profesi yang mengandalkan keahlian diri, skill dan jaza yang banyak dilakukan dan dilaksanakan dalam kehidupan masyarakat sehari-hari yang mana mereka masih banyak tidak paham dan belum mengerti mengeai adanya zakat profesi khususnya di lingkungan pemerintahan (kabupaten Bogor) sebagai salah satu motor penggerak sukses dan tidak nya pengelolaan Zakat Profesi ini. Sehingga penulis memberanikan diri untuk kembali mengkaji dan berusaha memahamkannya kepada masyarakat salah satunya lewat ditulisnya skripsi ini yang mengangkat tema dan judul: "Dampak Intruksi Bupati Tentang Zakat Profesi Terhadap Pegawai Dan Pengelolaan Zakat Di Bazis Kabupaten Bogor" (Studi Kasus Di Bazis Dan Pemerintahan Kabupaten Bogor).

\section{Pengertian Zakat}

Ditinjau dari segi bahasa, kata zakat mempunyai beberapa arti, yaitu albarakatu'keberkahan', al-namaa' pertumbuhan dan perkembangan', aththaharatu 'kesucian', dan ash-shalahu 'keberesan. ${ }^{13}$ Dalam pengertian yang sama secara etimologi adalah berkembang dan berkah, seperti dalam ungkapan zaka azzar'u (tanaman itu berkembang), atau zakat nafaqotu (nafkah itu berkah). Selain itu zakat juga dapat diartikan mensucikan, sebagaimana dalam firman Allah dalam surat as-Syams 91; 9, "Sesungguhnya beruntunglah orang yang mensucikan jiwanya". ${ }^{14}$ Sedangkan secara istilah, meskipun para ulama mengemukakannya dengan redaksi yang agak berbeda antara satu dan lainnya, akan tetapi pada prinsipnya sama, yaitu bahwa zakat itu adalah bagian dari harta dengan persyaratan tertentu, yang Allah SWT mewajibkan kepada pemiliknya, untuk diserahkan kepada yang berhak menerimanya, dengan persyaratan tertentu pula. ${ }^{15}$

${ }^{13}$ Hafidhuddin, Didin, Zakat Dalam Perekonomian Modern, Gema Insani, Jakarta, 2002, h. 7

${ }^{14}$ Muhammad, Abdul Aziz, Fiqih Ibadah, Pustaka Amzah, Jakarta 2009, h. 343

${ }^{15} \mathrm{Ibid}$, h. 7 
Hubungan antara pengertian zakat menurut bahasa dan dengan pengertian menurut istilah, sangat nyata dan erat sekali, yaitu bahwa harta yang dikeluarkan zakatnya akan menjadi berkah, tumbuh, berkembang dan bertambah, suci, dan beres (baik). Hal ini sebagaimana dinyatakan dalam surat at-Taubah: 103 dan surat ar-Ruum: 39

\section{Urgensi dan Hikmah Zakat}

Alquran menyatakan bahwa kesediaan berzakat dipandang sebagai indikator utama ketundukan seseorang terhadap ajaran Islam (QS. 9:5) dan QS, 9:11), ciri utama mukmin yang akan mendapatkan kebahagiaan hidup (QS. 23:4), dan ciri utama mukmin yang akan mendapatkan rahmat dan pertolongan Allah SWT (QS. 9:73 dan QS. 22:40-41). Kesediaan berzakat dipandang pula sebagai orang yang selalu berkeinginan untuk membersihkan diri dan jiwanya dari berbagai sifat buruk seperti bakhil, egois, rakus, dan tamak, sekaligus berkeinginan untuk selalu membersihkan, menyucikan, dan mengembangkan harta yang dimilikinya.

Sebaliknya, ajaran Islam memberikan peringatan dan ancaman yang keras terhadap orang yang enggan mengeluarkan zakat. Di akhirat kelak, harta benda yang disimpan dan ditumpuk tanpa dikeluarkan zakatnya, akan berubah menjadi azab bagi pemiliknya (QS. 9:34-35). Sementara dalam kehidupan dunia sekarang, orang yang enggan berzakat, menurut beberapa hadits Nabi, harta bendanya akan hancur. Dan jika keengganan ini memassal, maka Allah SWT akan menurunkan berbagai adzab, seperti musim kemarau yang panjang. Atas dasar itu, sahabat Abdullah ibnu Mas'ud menyatakan bahwa orang-orang yang beriman diperintahkan untuk menegakkan shalat dan mengeluarkan zakat. Siapa yang tidak berzakat, tidak ada shalat baginya. Rasulullah Saw. pernah menghukum Tsa'labah yang enggan berzakat dengan isolasi yang berkepanjangan. Tak ada seorang sahabat pun yang mau berhubungan dengannya, meski hanya sekedar betegur sapa. Khalifah Abu Bakar Ash-Shiddiq berktekad akan memerangi orang-orang yang mau shalat tetapi enggan untuk berzakat. Ketegasan sikap ini menunjukkan bahwa perbuatan meninggalkan zakat adalah suatu kedurhakaan, dan bila hal ini dibiarkan, maka akan memunculkan perbagai kedurhakaan dan kemaksiatan yang lain. ${ }^{16}$

${ }^{16}$ Hafidhuddin, Didin, Zakat Dalam Perekonomian Modern, Gema Insani, Jakarta, 2002, h.

2.

Mizan: Jurnal IImu Syariah. Volume 1 No 2 Desember 2013. ISSN: 2089-032X - 212 
Kewajiban menunaikan zakat yang demikian tegas dan mutlak itu oleh karena di dalam ajaran Islam ini terkandung hikmah dan manfaat yang demikian besar dan mulia, baik yang berkaitan dengan muzakki, mustahiq, harta benda yang dikeluarkan zakatnya, maupun bagi masyarakat secara keseluruhan. Hikmah dan manfaat tersebut, antara lain adalah:

Pertama, sebagai perwujudan iman kepada Allah SWT, mensyukuri nikmat-Nya, menumbuhkan akhlak mulia dengan memiliki rasa kepedulian yang tinggi, menghilangkansifat kikir dan rakus, menumbuhkan ketenangan hidup, sekaligus mengembangkan dan menyucikan harta yang dimiliki (QS. 9:103, QS. 30:39, QS. 14:7).

Kedua, karena zakat merupakan hak bagi mustahiq, maka berfungsi untuk menolong, membantu dan membina mereka, terutama golongan fakir miskin kearah kehidupan yang lebih baik dan lebih sejahtera, sehingga mereka dapat memnuhi kebutuhan hidupnya dengan layak, dapat beribadah kepada Allah SWT, terhindar dari bahaya kekufuran, sekaligus menghilangkan sifat iri, dengki dan hasad yang mungkin timbul dari kalangan mereka ketika melihat golongan kaya yang berkecukupan hidupnya. Zakat sesungguhnya bukan sekedar untuk memenuhi kebutuhan yang bersifat konsumtif yang sifatnya sesaat, akan tetapi memberikan kecukupan dan kesejahteraan kepada mereka, dengan cara menghilangkan atau memperkecil penyebab yang menjadikan kehidupan mereka miskin dan menderita.

Ketiga, sebagai pilar jama'i antara kelompok aghniya yang berkecukupan hidupnya, dengan para mujahid yang waktunya sepenuhnya untuk berjuang di jalan Allah, sehingga tidak memiliki waktu yang cukup untuk berusaha bagi kepentingan nafkah diri dan keluarganya. Firman Allah dalam QS. Al-Baqarah ayat 273.

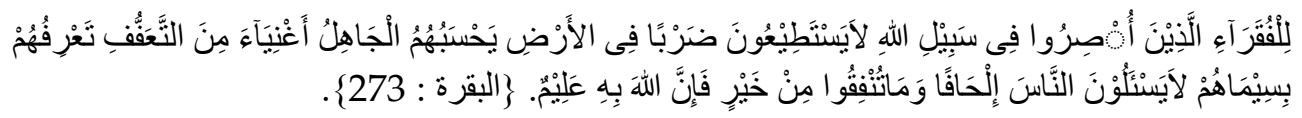

"(Berinfaklah) kepada orang-orang fakir yang terikat (oleh jihad) di jalan Allah; mereka tidak dapat (berusaha) di muka bumi; orang yang tidak tahu menyangka mereka orang kaya karena memelihara diri dari meminta-minta. Kami kenal mereka dengan melihat sifat-sifat mereka, mereka tidak meminta kepada orang secara mendesak. Dan apa saja yang baik yang kamu nafkahkan (di jalan Allah), maka sesungguhnya Allah Maha Mengetahui". (QS. AlBaqarah : 273). 
Keempat, sebagai salah satu sumber dana bagi pembangunan sarana maupun prasarana yang harus dimiliki ummat Islam, seperti sarana pendidikan, kesehatan, maupun sosial-ekonomi, dan terlebih lagi bagi peningkatan kualitas sumber daya manusia.

"Dan orang-orang yang beriman, laki-laki dan perempuan, sebahagian mereka (adalah) menjadi penolong bagi sebahagian yang lain. Mereka memyuruh (mengerjakan) yang ma'ruf, dan mencegah dari yang munkar, mendirikan shalat, menunaikan zakat, dan mereka taat kepada Allah dan Rasul-Nya. Mereka itu akan diberi rahmat oleh Allah; sesungguhnya Allah Maha Perkasa lagi Maha Bijaksana". (QS. At-Taubah : 71).

Kelima, untuk memasyarakatkan etika bisnis yang benar, karena zakat tidak akan diterima dari harta yang didapatkan dengan cara yang bathil (alHadits). Zakat mendorong pula ummat Islam untuk menjadi muzakki yang sejahtera hidupnya.

Keenam, dari sisi pembangunan kesejahteraan ummat, zakat merupakan salah satu instrumen pemerataan pendapatan. Dengan zakat yang dikelola dengan baik, dimungkinkan membangun pertumbuhan ekonomi sekaligus pemerataan pendapatan, economic growth with equity. ${ }^{17}$

\section{Harta Sebagai Sumber Zakat}

Secara umum dan global Alquran menyatakan bahwa zakat itu diambil dari setiap harta yang kita miliki, seperti dikemukakan dalam surat at-Taubah: 103 dan juga diambil dari setiap hasil usaha yang baik dan halal, seperti juga digambarkan dalam surat al-Baqarah : 267. Ketika menafsirkan ayat tersebut (at-Taubah: 103) Imam al-Qurthubi (wafat tahun $671 \mathrm{H}$ ) mengemukakan bahwa zakat itu diambil dari semua harta yang dimiliki, meskipun kemudian Sunnah Nabi mengemukakan rincian harta yang wajib dikeluarkan zakatnya. Hal yang sama dikemukakan pula oleh Imam athThabari (wafat tahun 310H) dala kitab Jaami' al-Bayan fi Ta'wil Al Qur'an. ${ }^{18}$

Yusuf al-Qardhawi menyatakan bahwa yang dimaksud dengan harta (al-amwal) merupakan bentuk jamak dari kata maal, dan maal bagi orang arab, yang dengan bahasanya Alquran diturunkan, adalah segala sesuatu

${ }^{17}$ Hafidhuddin, Didin, Risalah Zakat, Gema Insani, Jakarta, 2002, h. 7

${ }^{18}$ Hafidhuddin, Didin, Zakat Dalam Perekonomian Modern, Gema Insani, Jakarta, 2002, h. 
yang diinginkan sekali oleh manusia untuk menyimpan dan memilikinya. Ibnu Asyr, sebagaimana dikutip Yusuf al-Qardhawi, mengemukakan bahwa harta itu pada mulanya berarti emas dan perak, tetapi kemudian berubah pengertiannya menjadi segala barang yang disimpan dan dimiliki.

Sejalan dengan hal tersebut, Zarqa mengemukakan suatu defenisi yang memungkinkan tercakupnya berbagai harta, sesuai dengan perkembagan keadaan zaman. Ia menyatakan bahwa harta itu adalah segala sesuatu yang konkret bersifat material yang mempunyai nilai dalam pandangan manusia dan dimungkinkan untuk menyimpannya sampai waktu yang dibutuhkan. Sebagian ulama lain menambahkan pengertian dengan menyatakan bahwa harta itu disamping diinginkan oleh manusia, juga dimungkinkan diperjualbelikan atau dimanfaatkan. ${ }^{19}$

\section{Landasan Teori Tentang Zakat Profesi}

Zakat profesi adalah zakat yang dikeluarkan dari penghasilan dari hasil usaha tertentu (hasil profesi) bila telah mencapai nisab. Profesi dimaksud mencakup profesi pegawai negeri atau swasta, konsultan, dokter, notaris, akuntan, artis, wiraswasta, dll. ${ }^{20}$ Atau dalam Wikipedia bahasa Indonesia, ensiklopedia bebas dikatakan bahwa Zakat Profesi adalah zakat yang dikeluarkan dari penghasilan profesi (hasil profesi) bila telah mencapai nisab. ${ }^{21}$

Dalam pendapat yang lain dikatakan bahwa Zakat Profesi adalah zakat yang ditarik dari hasil usaha yang bergerak dibidang jasa, baik yang berpenghasilan tetap maupun tidak tetap. Seperti halnya manajer, konsultan, notaries, dokter, bidan, kontraktor, guru dan lain-lain. Termasuk para karyawan yang menerima gaji atau upah perbulan. Penjelasan zakat ini berasal dari ijtihad para ulama. ${ }^{22}$ Yusuf Al Qardhawi dalam bukunya Fiqhuz Zakat (terjemahan) mengatakan bahwa pekerjaan yang menghasilkan uang ada dua macam, yang pertama adalah pekerjaan yang dikerjakan sendiri tanpa tergantung pada orang lain, seperti seorang dokter, insinyur, advokad, seniman, penjahit tukang kayu dan lain-lain. Sedangkan yang kedua adalah

\footnotetext{
${ }^{19}$ Ibid, h. 16

${ }^{20}$ Idris, Sofwan, Gerakan Zakat dalam Pemberdayaan ekonomi umat, IKAPI Jakarta h. 221

${ }^{21}$ http://id.wikipedia.org/wiki/Zakat_Profesi

22 Satria. M. Zein. Media Dakwah. 1992, H. 50
} 
pekerjaan yang dikerjakan seseorang buat pihak lain - baik di pemerintahan, perusahaan, maupun perorangan yang mendapatkan upah atau honorium. ${ }^{23}$

Di dalam Islam perintah zakat merupakan fungsi yang jelas untuk mensucikan harta dan jiwa yang mengeluarkannya, dan yang terbentuk dalam dua hal yaitu zakat mal dan zakat fitrah yang pengeluarannya di atur syarat dan ketentuannya baik mengenai jumlah maupun waktu dan kadarnya.

Zakat profesi sendiri merupakan zakat yang dikenakan pada setiap profesi tertentu, yang mendatangkan penghasilan serta memenuhi nisab (yaitu batas minimum untuk bisa berzakat). Dengan kata lain setiap penghasilan melalui kegiatan professional yang apabila telah mencapai nisab, maka wajib dikeluarkan zakatnya. Hal ini berdasarkan nash-nash yang bersifat umum, misalnya Firman Allah dalam surat At-Taubah;103 dan surat al-Baqorah ayat 267 dan juga firman Nya dalam surat adz-dzariyaat: 19.

Firman Allah SWT: "Dan pada harta-harta mereka ada hak untuk orang miskin yang meminta dan orang miskin yang tidak dapat bahagian". (QS. Adz-Dzaariyaat 51: 19). "Wahai orang-orang yang beriman, infaqkanlah (zakat) sebagian dari hasil usahamu yang baik-baik dan sebagian dari apa yang Kami keluarkan dari bumi untuk kamu". (QS Al Baqarah: 267)

Sayyid Quthub (wafat 1965) dalam tafsirnya Fi Zhilalil Qur'an ketika menafsirkan firman Allah dalam surat al-Baqarah ayat 267 menyatakan, nash ini mencakup seluruh aspek yang dikeluarkan Allah Swt dari dalam dan atas bumi, seperti hasil-hasil pertanian, maupun hasil pertambangan seperti minyak yang semuanya wajib dikeluarkan zakatnya dengan ketentuan dan kadar sebagaimana diterangkan dalam sunnah Rasulullah Saw, baik yang sudah diketahui secara langsung, maupun yang diqiyaskan kepadanya. Alqurtubi (wafattahun $671 \mathrm{H}$ ) dalam tafsir al-jami' li ahkaam Alquran menyatakan bahwa yang dimaksud dengan kata-kata hakkun ma'lum (hak yang pasti) pada adz-Dzariyaat 19 adalah zakat yang diwajibkan, artinya semua harta yang dimiliki dan semua penghasilan yang didapatkan, jika telah memenuhi persyaratan kewajiban zakat, maka harus dikeluarkan zakatnya. ${ }^{24}$

Zakat profesi memang tidak dikenal di zaman Rasulullah SAW bahkan hingga masa berikutnya selama ratusan tahun. Bahkan kitab-kitab

${ }^{23}$ Qardhawi, Yusuf. Hukum Zakat, Litera antarNusa, Jakarta 2004, hlm. 459

${ }^{24}$ Hafidhuddin, Didin, Zakat Dalam Perekonomian Modern, Gema Insani, Jakarta, 2002,

hlm 95 
fiqih yang menjadi rujukan umat ini pun tidak mencantumkan bab zakat profesi di dalamnya. ${ }^{25}$

Wacana zakat profesi itu merupakan ijtihad pada ulama di masa kini yang nampaknya berangkat dari ijtihad yang cukup memiliki alasan dan dasar yang juga cukup kuat. Salah satunya adalah rasa keadilan seperti yang anda utarakan tersebut. Harus diingat bahwa meski di zaman Rasulullah SAW telah ada beragam profesi, namun kondisinya berbeda dengan zaman sekarang dari segi penghasilan. Dalam masalah ketentuan harta yang wajib dizakati, memang ada perbedaan cara pandang di kalangan ulama. Ada kalangan yang sependapat dan ada juga yang menentang pendapat adanya zakat profesi ini.

\section{Argumentasi Mengenai zakat Profesi}

Mereka mendasarkan pandangan bahwa masalah zakat sepenuhnya masalah ubudiyah, sehingga segala macam bentuk aturan dan ketentuannya hanya boleh dilakukan kalau ada petunjuk yang jelas dan tegas atau contoh langsung dari Rasulullah SAW. Bila tidak ada, maka tidak perlu membuatbuat. Di antara mereka yang berada dalam pandangan seperti ini adalah fuqaha kalangan zahiri seperti Ibnu Hazm dan lainnya dan juga jumhur ulama. Kecuali mazhab hanafiyah yang memberikan keluwasan dalam kriteria harta yang wajib dizakati.

Umumnya ulama hijaz dan termasuk juga Dr. Wahbah Az-Zuhaily pun menolak keberadaan zakat profesi sebab zakat itu tidak pernah dibahas oleh para ulama salaf sebelum ini. Umumnya kitab fiqih klasik memang tidak mencantumkan adanya zakat profesi. Apalagi di zaman Rasulullah dan salafus sholeh sudah ada profesi-porfesi tertentu yang mendapatkan nafkah dalam bentuk gaji atau honor. Namun tidak ada keterangan sama sekali tentang adanya ketentuan zakat gaji atau profesi. Bagaimana mungkin sekarang ini ada dibuat-buat zakat profesi.

Para pendukung zakat profesi tidak kalah kuatnya dalam berhujjah. Misalnya mereka menjawab bahwa profesi dimasa lalu memang telah ada, namun kondisi sosialnya bebeda dengan hari ini. Menurut para pendukung zakat profesi, yang menjadi acuan dasarnya adalah kekayaan seseroang.

${ }^{25}$ Idris, Sofwan, Gerakan Zakat dalam Pemberdayaan ekonomi umat, IKAPI Jakarta hlm 222 
Menurut analisa mereka, orang-orang yang kaya dan memiliki harta saat itu masih terbatas seputar para pedagang, petani dan peternak. Ini berbeda dengan zaman sekarang, di mana tidak semua pedagang itu kaya, bahkan umumnya peternak dan petani di negeri ini malah rata-rata hidup miskin.

Sebaliknya, profesi orang-orang yang dahulu tidak menghasilkan sesuatu yang berarti, kini menjadi profesi yang membuat mereka menjadi kaya dengan harta berlimpah. Penghasilan mereka jauh melebihi para pedagang, petani dan peternak dengan berpuluh kali bahkan ratusan kali. Padahal secara teknis, apa yang mereka kerjakan jauh lebih simpel dan lebih ringan dibanding keringat para petani dan peternak itu. ${ }^{26}$

Inilah salah satu pemikiran yang mendasari ijtihad para ulama hari ini untuk menetapkan zakat profesi yang intinya adalah azas keadilan. Namun dengan tidak keluar dari mainframe zakat itu sendiri yang filosofinya adalah menyisihkan harta orang kaya untuk orang miskin. Yang berubah adalah fenomena masyarakatnya dan aturan dasar zakatnya adalah tetap. Karena secara umum yang wajib mengeluarkan zakat adalah mereka yang kaya dan telah memiliki kecukupan. Namun karena kriteria orang kaya itu setiap zaman berubah, maka bisa saja penentuannya berubah sesuai dengan fenomena sosialnya.

Di zaman itu, penghasilan yang cukup besar dan dapat membuat seseorang menjadi kaya berbeda dengan zaman sekarang. Di antaranya adalah berdagang, bertani dan beternak. Sebaliknya, di zaman sekarang ini berdagang tidak otomatis membuat pelakunya menjadi kaya, sebagaimana juga bertani dan beternak. Bahkan umumnya petani dan peternak di negeri kita ini termasuk kelompok orang miskin yang hidupnya serba kekuarangan.

Sebaliknya, profesi-profesi tertentu yang dahulu sudah ada, tapi dari sisi pemasukan, tidaklah merupakan kerja yang mendatangkan materi besar. Dan di zaman sekarang ini terjadi perubahan, justru profesi-profesi inilah yang mendatangkan sejumlah besar harta dalam waktu yang singkat. Seperti dokter spesialis, arsitek, komputer programer, pengacara dan sebagainya. Nilainya bisa ratusan kali lipat dari petani dan peternak miskin di desa-desa. Perubahan sosial inilah yang mendasari ijtihad para ulama hari ini untuk

\footnotetext{
${ }^{26}$ Hafidhuddin, Didin, Risalah Zakat Profesi, Makalah seputar zakat profesi, Jakarta, 2002, hlm 35
} 
melihat kembali cara pandang kita dalam menentukan siapakah orang kaya dan siapakah orang miskin? ${ }^{27}$

Intinya zakat itu adalah mengumpulkan harta orang kaya untuk diberikan pada orang miskin. Di zaman dahulu, orangkaya identik dengan pedagang, petani dan peternak. Tapi di zaman sekarang ini, orang kaya adalah para profesional yang bergaji besar. Zaman berubah namun prinsip zakat tidak berubah. Yang berubah adalah realitas di masyarakat. Tapi intinya orang kaya menyisihkan uangnya untuk orang miskin. Dan itu adalah intisari zakat. Sehingga dalam keyakinan mereka, bila para ulama terdahulu menyaksikan realita sosial di hari ini, mereka akan terlebih dahulu menambahkan bab zakat profesi dalam kitab-kitab mereka.

Bila dikaitkan bahwa zakat berkaitan dengan masalah ubudiyah, memang benar. Tapi ada wilayah yang tidak berubah secara prinsip dan ada wilayah operasional yang harus selalu menyesuaikan diri dengan zaman. Prinsip yang tidak berubah adalah kewajiban orang kaya menyisihkan harta untuk orang miskin. Dan wajib adanya amil zakat dalam penyelenggaraan zakat. Dan kententuan nisab dan haul dan seterusnya. Semuanya adalah aturan 'baku' yang didukung oleh nash yang kuat. Tetapi menentukan siapakah orang kaya dan dari kelompok mana saja, harus melihat realitas masyarakat. Dan ketika ijtihad zakat profesi digariskan, para ulama pun tidak semata-mata mengarang dan membuat-buat aturan sendiri. Mereka pun menggunakan metodologi fikih yang baku dengan beragam qiyas atas zakat yang sudah ditentukan sebelumnya.

Adanya perkembangan ijtihad justru harus disyukuri karena dengan demikian agama ini tidak menjadi stagnan dan mati. Apalagi metodologi ijtihad itu sudah ada sejak masa Rasulullah SAW dan telah menunjukkan berbagai prestasinya dalam dunia Islam selama ini. Dan yang paling penting, metode ijtihad itu terjamin dari hawa nafsu atau bid 'ah yang mengada-ada.

Pada hakikatnya, kitab-kitab fiqih karya para ulama besar yang telah mengkodifikasi hukum-hukum Islam dari Al-Quran dan As-Sunnah adalah hasil ijtihad yang gemilang yang menghiasi peradaban Islam sepanjang sejarah. Semua aturan ibadah mulai dari wudhu', shalat, puasa, haji dan zakat yang kita pelajari tidak lain adalah ijtihad para ulama dalam memahami nash Al-Quran dan As-Sunnah.

${ }^{27}$ Ibid hlm 25 
Kehidupan manusia sudah mengami banyak perubahan besar. Dengan menggunakan pendekatan seperti itu, maka hanya petani gandum dan kurma saja yang wajib bayar zakat, sedangkan petani jagung, palawija, padi dan makanan pokok lainnya tidak perlu bayar zakat. Karena contoh yang ada hanya pada kedua tumbuhan itu saja. Sementara disisi lain ada kalangan yang melakukan ijtihad dan penyesuaian sesuai dengan kondisi yang ada. Mereka misalnya mengqiyas antara beras dengan gandum sebagai sama-sama makanan pokok, sehingga petani beras pun wajib mengeluarkan zakat.

Bahkan ada kalangan yang lebih jauh lagi dalam melakukan qiyas, sehingga mereka mewajibkan petani apapun untuk mengeluarkan zakat. Maka petani cengkeh, mangga, bunga-bungaan, kelapa atau tumbuhan hiasan pun kena kewajiban untuk membayar zakat. Menurut mereka adalah sangat tidak adil bila hanya petani gandunm dan kurma saja yang wajib zakat, sedangkan mereka yang telah kaya raya karena menanam jenis tanaman lain yang bisa jadi hasilnya jauh lebih besar, tidak terkena kewajiban zakat.

Di antara mereka yang berpendapat seperti ini antara lain adalah AlImam Abu Hanifah dan para pengikutnya. Dan ide munculnya zakat profesi kira-kira lahir dari sistem pendekatan fiqih gaya Al-Hanafiyah ini, di mana mereka menyebutkan bahwa kewajiban zakat adalah dari segala rizki yang telah Allah SWT berikan sehingga membuat pemiliknya berkecukupan atau kaya. Dan semua sudah sepakat bahwa orang kaya wajib membayar zakat. Hanya saja menurut kalangan ini, begitu banyak terjadi perubahan sosial dalam sejarah dan telah terjadi pergeseran besar dalam jenis usaha yang melahirkan kekayaan.

Dahulu belum ada dokter spesialis, lawyer atau konsultan yang cukup sekali datang bisa mendapatkan harta dalam jumlah besar dan mengalir lancar ke koceknya. Misalnya seorang dokter spesialis yang berpraktek hanya dalam hitungan menit, tapi honornya berjuta. Dibandingkan dengan petani di kampung yang kehujanan dan kepanasan sedangkan hasilnya pas-pasan bahkan sering nombok, maka alangkah sangat tidak adilnya agama ini, bila si petani miskin wajib bayar zakat sedangkan dokter spesialis itu bebas dari beban. Karena itulah mereka kemudian merumuskan sebuah pos baru yang pada dasarnya tidak melanggar ketentuan Allah SWT atas kewajiban bayar zakat bagi orang kaya. Hanya saja sekarang ini perlu dirumuskan secara cermat, siapakah orang yang bisa dibilang kaya itu. Dan para profesional itu tentu berada pada urutan terdepan dalam hal kekayaan dibandingkan dengan 
orang kaya secara tradisional yang dikenal di zaman dahulu. Untuk itu agar mereka ini juga wajib mengeluarkan zakat, maka pos zakat mereka itu disebut dengan zakat profesi.

Bila dirunut ke belakang, sebenarnya zakat profesi ini bukanlah hal yang sama sekali baru, karena ada banyak kalangan salaf yang pernah menyebutkannya di masa lalu meski tidak/ belum populer seperti di masa kini. Namun begitulah, kita tahu bahwa di dalam tubuh umat ini memang ada khilaf dalam cara pandang terhadap masalah zakat, sehingga ada yang mendukung zakat profesi di satu pihak karena lebih logis dan nalar dan di pihak lain menentangnya karena dianggap tidak ada masyru iyahnya.

Beberapa alasan kewajiban zakat profesi, antara lain:

Pertama, ayat-ayat Alquran yang bersifat umum yang mewajibkan semua jenis harta untuk dikeluarkan zakatnya.

Kedua, berbagai pendapat para ulama terdahulu maupun sekarang, meskipun dengan menggunakan istilah yang berbeda. Sebagian dengan menggunakan istilah yang bersifat umum yaitu al-amwaal, sementara sebagian lagi secara khusus memberikan istilah dengan istilah al-mustafad seperti teradapat dalam fiqh zakat dan al-figh al-Islamy wa 'Adillatuhu.

Ketiga, dari sudut keadilan - yang merupakan ciri utama ajaran Islam penetapan kewajiban zakat pada setiapa harta yang dimiliki akan terasa sangat jelas, dibandingkan dengan hanya menetapkan kewajiban zakat pada komoditas-komoditas tertentu saja yang konvensional. Petani yang saat ini kondisinya secara umum kurang beruntung, tetapi harus berzakat, apabila hasil pertaniannya telah mencapaia nishab. Karena itu sangat adil pula, apabila zakat inipun bersifat wajib pada penghasilan yang didapatkan para dokter, para ahli hukum, konsultan dalam berbagai bidang, para dosen, para pegawai dan karyawan yang memiliki gaji tinggi, dan profesi lainnya.

Keempat, sejalan dengan perkembangan kehidupan ummat manusia, khususnya dalam bidang ekonomi, kegiatan penghasilan melalui keahlian dan profesi ini akan semakin berkembang dari waktu ke waktu. Bahkan akan menjadi kegiatan ekonomi yang utama, seperti terjadi di negara-negara industri sekarang ini. Penetapan kewajiban zakat kepadanya, menunjukkan betapa hukum Islam sangat aspiratif dan 
responsif terhadap perkembangan zaman. Afif Abdul Fatah Thabari ${ }^{28}$ menyatakan bahwa aturan dalam Islam itu bukan saja sekedar berdasarkan pada keadilan bagi seluruh ummat manusia, akan tetapi sejalan dengan kemaslahatan dan kebutuhan hidup manusia, sepanjang zaman dan keadaan, walaupun zaman itu bebeda dan berkembang dari waktu ke waktu. ${ }^{29}$

\section{Kriteria Zakat profesi dan kadar Nisabnya}

Yang termasuk dalam zakat profesi menurut para pendukungnya adalah semua pemasukan dari hasil kerja dan usaha. Bentuknya bisa berbentuk gaji, upah, honor, insentif, mukafaah, persen dan sebagainya. Baik sifatnya tetap dan rutin atau bersifat temporal atau sesekali. Namun bagaimanakah menghitung pengeluaran itu? Apakah berdaasrkan pemasukan kotor ataukah setelah dipotong dengan kebutuhan pokok? Dalam hal ini ada dua kutub pendapat. Sebagian mendukung tentang pengeluaran dari pemasukan kotor dan sebagian lagi mendukung pengeluaran dari pemasukan yang sudah bersih dipotong dengan segala hajat dasar kebutuhan hidup. Dalam kitab Fiqih Zakat, Dr. Yusuf Al-Qardhawi menyebutkan bahwa untuk mereka yang berpenghasilan tinggi dan terpenuhi kebutuhannya serta memang memiliki uang berlebih, lebih bijaksana bila membayar zakat dari penghasilan kotor sebelum dikurangi dengan kebutuhan pokok.

Misalnya seseorang bergaji 200 juta setahun, sedangkan kebutuhan pokok anda perbulannya sekitar 2 juta atau setahun 24 juta. Maka ketika menghitung pengeluaran zakat, hendaknya dari penghasilan kotor itu dikalikan 2, 5\%. Namun masih menurut Al-Qardhawi, bila anda termasuk orang yang bergaji pas-pasan bahkan kurang memenuhi standar kehidupan, kalaupun anda diwajibkan zakat, maka penghitungannya diambil dari penghasilan bersih setelah dikurangi hutang dan kebutuhan pokok lainnya. Bila sisa penghasilan anda itu jumlahnya mencapai nisab dalam setahun (Rp 1.300.000, -), barulah anda wajib mengeluarkan zakat sebesr 2, 5\% dari penghasilan bersih itu. Nampaknya jalan tengah yang diambil Al-Qardhawi ini lumayan bijaksana, karena tidak memberatkan semua pihak. Dan masingmasing akan merasakan keadilan dalam syariat Islam. Yang penghasilan pashlm. 300 .

${ }^{28}$ Afif Abdul Fatah ath-Thabari, Ruh al-Din al-Islamy, (Damaskus : Daar el-Fikr, 1966),

${ }^{29}$ Hafidhuddin, Didin, Risalah Zakat Profesi, Kumpulan materi zakat, Jakarta 2006 
pasan, membayar zakatnya tidak terlalu besar, dan yang penghasilannya besar, wajar bila membayar zakat lebih besar, toh semuanya akan kembali.

Kedua pendapat ini memiliki kelebihan dan kekuarangan. Buat mereka yang pemasukannya kecil dan sumber penghidupannya hanya tergantung dari situ, sedangkan tanggungannya lumayan besar, maka pendapat pertama lebih sesuai untuknya.

Pendapat kedua lebih sesuai bagi mereka yang memiliki banyak sumber penghasilan dan rata-rata tingkat pendapatannya besar sedangkan tanggungan pokoknya tidak terlalu besar.

Zakat profesi memang tidak terdapat rinciannya dalam kitab-kitab fiqih yang membahas masalah zakat. Oleh karena itu nisab dan kadar zakat yang harus dikeluarkan perlu dicari bandingannya pada jenis-jenis harta yang wajib dizakati, yang dalam hal ini perlu dilakukan qiyas atau penyamaan kepada yang lebih mirip kepadanya dari segi nisab dan kadarnya yang wajib dikeluarkan zakatnya.

Yusuf al-Qardhawi dalam kitab fiqih zakat cenderung menyamakan dengan zakat tijaroh (perdagangan) karena sama-sama menjual. Yang satu menjual barang sedang yang satunya menjual jasa, yang keduanya sama-sama mengandung resiko. Berdasarkan pada pandangan itulah zakat profesi diqiyaskan dengan zakat tijaroh. Zakat tijaroh nisabnya sekitar 90 gram mas dikali denagan harga mas sekarang, dan yang wajib dikeluarkan adalah 2,5\%. Sedangkan para ulama umumnya mengqiyaskan zakat profesi dengan zakat tanaman. termasuk ketika mengqiyaskan nisab. Maka nishab zakat profesi sesuai dengan zakat tanaman, yaitu setiap menerima panen atau penghasilan dan besarnya adalah 5 wasaq atau setara dengan 652, $8 \mathrm{~kg}$ gabah. Dan tunaikanlah haknya di hari memetik hasilnya (dengan dikeluarkan zakatnya)..." (QS Al-An`am 141 ).

Rasulullah SAW bersabda: 'Tidak ada zakat pada hasil tanaman yang kurang dari lima wasaq' (HR Ahmad dan al-Baihaqi dengan sanad jayyid).

Dan tidak ada zakat pada kurma yang kurang dari lima wasaq' (HR Muslim). 1 wasaq $=60$ sha'$^{\prime}, 1$ sha ${ }^{\prime}=2,176 \mathrm{~kg}$, maka 5 wasaq $=5 \times 60 \times 2,176=$ $652,8 \mathrm{~kg}$ gabah. Jika dijadikan beras sekitar $520 \mathrm{~kg}$. Maka nishab zakat profesi seharga dengan $520 \mathrm{~kg}$ beras. Yaitu sekitar Rp 1.300.000, -. Nishab ini adalah jumlah pemasukan dalam satu tahun. Artinya bila penghasilan seseorang dikumpulkan dalam satu tahun bersih setelah dipotong dengan kebutuhan 
pokok dan jumlahnya mencapai Rp 1.300.000, - maka dia sudah wajib mengeluarkan zakat profesinya. Ini bila mengacu pada pendapat pertama. Dan bila mengacu kepada pendapat kedua, maka penghasilannya itu dihitung secara kotor tanpa dikurangi dengan kebutuhan pokoknya. Bila jumlahnya dalam setahun mencapai Rp 1.300.000, -, maka wajiblah mengeluarkan zakat.

Zakat profesi dibayarkan saat menerima pemasukan karena diqiyaskan kepada zakat pertanian yaitu pada saat panen atau saat menerima hasil. Penghasilan profesi dari segi wujudnya berupa uang. Dari sisi ini, ia berbeda dengan hasil tanaman, dan lebih dekat dengan 'naqdain ' (emas dan perak). Oleh sebab itu, para ulama menyebutkan bahwa kadar zakat profesi yang dikeluarkan diqiyaskan berdasarkan zakat emas dan perak, yaitu `rub 'ul usyur`atau 2,5\% dari seluruh penghasilan kotor.

Nash yang menjelaskan kadar zakat 'naqdaian` sebanyak 2, 5\% adalah sabda Rasulullah SAW: Bila engkau memiliki 20 dinar (emas) dan sudah mencapai satu tahun, maka zakatnya setengah dinar (2, 5\%)' (HR Ahmad, Abu Dawud dan al-Baihaqi). Berikanlah zakat perak dari 40 dirham dikeluarkan satu dirham. Tidak ada zakat pada 190 dirham (perak), dan jika telah mencapai 200 dirham maka dikeluarkan lima dirham ' (HR Ashabus Sunan). Sehingga jadilah nishab zakat profesi 2, 5\% dari hasil kerja atau usaha.

\section{Pengertian Badan Amil Zakat}

Kata BAZIS adalah kependekan dari Badan Amil Zakat, Infak dan Shadaqah, pengertian BAZIS dapat ditemukan antara lain dalam undangundang RI No 38 Tahun 1999 tentang pengelolaan zakat yang memberi pengertian antara lain yaitu suatu lembaga yang mempunyai tugas pokok mengumpulkan, mendistribusikan dan mendayagunakan harta zakat sesuai dengan ketentuan agama. Atau dalam pengertian lain yaitu lembaga yang dibentuk oleh pemerintah daerah dengan tugas pokok mengumpulkan danadana zakat, infaq dan shadaqoh dari masyarakat muslim yang pengelolaannya diatur dalam Undang-undang No. 38 tahun 1999 yang mencakup kegiatan perencanaan, pengorganisasian, pelaksanaan, dan pengawasan untuk mendistribusikan serta didayagunakan kepada yang berhak menerimanya (mustahik). Dalam keputusan menteri agama Republik Indonesia tentang pelaksanaan Undang-undang No 38 tahun 1999 dijelaskan bahwa Badan Amil Zakat adalah organisasi pengelola zakat yang dibentuk oleh pemerintah yang terdiri dari unsur masyarakat dan pemerintah dengan 
tugas mengumpulkan, mendistribusikan dan mendayagunakan zakat dengan ketentuan agama. Sebagai lembaga publik yang tidak berorientasi pada keuntungan (Non Profit Organization), BAZIS berperan sebagai lembaga pengelola dana Zakat, ifaq dan shadaqoh. Disamping itu Badan Amil Zakat mempunyai unit pengumpul zakat disemua tingkatan dengan tugas mengumpulkan zakat untuk melayani muzakki yang berada pada tingkat desa/kelurahan, sampai pada tingkat instansi-instansi pemerintahan atau swasta.

Susunan organisasi dan tata kerja Badan Amil Zakat meliputi Badan Amil Zakat tingkat Nasional yang berkedudukan di Ibu Kota Negara, Badan Amil Zakat Provinsi berkedudukan di Ibu Kota Provinsi, Badan Amil Zakat Daerah Kabupaten dan Kota berkedudukan di ibu kota kabupaten dan kota, dan Badan Amil Zakat tingkat kecamatan yang berkedudukan di pusat kecamatan.

Badan Amil Zakat Infaq dan shadaqah (BAZIS) secara garis besar adalah Badan atau organisai yang bertugas mengumpulkan dan membagikan harta zakat, infaq dan shadaqah yang dibentuk oleh pemerintah, sedangkan pengurus ZIS sendiri disebut 'Amilin. ${ }^{30}$

\section{Kriteria dan Syarat-syarat Amil Zakat}

Yusuf Al-Qardhawi dalam bukunya, Figh Zakat, menyatakan bahwa seseorang yang ditunjuk sebagal amil zakat atau pengelola zakat, harus memiliki beberapa persyaratan sebagai berkut:

Pertama, Beragama Islam. Zakat adalah salah satu urusan utama kaum muslimin yang termasuk rukun Islam (rukun Islam ketiga), karena itu sudah saatnya apabila urusan penting kaum muslimin ini diurus oleh sesama muslim. Kedua, Mukallaf, yaitu orang dewasa yang sehat akal pikirannya, ${ }^{31}$ yang siap menerima tanggung jawab mengurus urusan umat. Ketiga, Memiliki sifat amanah atau jujur. Sifat ini sangat penting karena berkaitan dengan kepercayaan umat. Artinya para muzakki akan dengan rela menyerahkan zakatnya melalui lembaga pengelola zakat, jika lembaga ini memang patut dan layak dipercaya. Keamanahan ini diwujudkan dalam bentuk transparansi (keterbukaan) dalam menyampaikan laporan

\footnotetext{
${ }^{30}$ Juwaini, ahmad, Membangun Peradapan Zakat, IMZ Jakarta 2007

${ }^{31}$ Qardhawi, Yusuf, Hukum Zakat, Litera antarNusa, Jakarta, 2004. hlm. 552
} 
pertanggung jawaban secara berkala dan juga ketetapan penyalurannya sejalan dengan ketentuan syari'ah islamiyyah. Di dalam Alquran dikisahkan sifat utama Nabi Yusuf a.s. yang mendapatkan kepercayaan menjadi bendaharawan negara Mesir, yang saat itu Mesir dilanda musim paceklik sebagai akibat dari kemarau panjang. Beliau berhasil membangun kembali kesejahteraan masyarakat, karena kemampuannya menjaga amanah. Perhatikan firman-Nya dalam QS. Yusuf ayat 55.

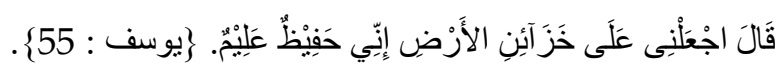

"Berkata Yusuf: "Jadikanlah aku bendaharawan negara (Mesir); sesungguhnya aku adalah orang yang pandai menjaga, lagi berpengetahuan." (QS. Yusuf : 55).

Demikian pula sifat keamanahan yang sangat menonjol dari para petugas zakat di zaman Rasulullah Saw. dan pada zaman khulafaur-rasyidin yang empat, menyebabkan baitul maal tempat menampung zakat selalu penuh terisi dengan harta zakat, untuk kemudian segera disalurkan kepada orang yang berhak menerimanya. Dalam periode Daulah Bani Umayyah yang berlangsung selama hampir sembilan puluh tahun $(41-127 \mathrm{H})$, tampil salah seorang khalifahnya yang sangat terkenal, yaitu Umar bin Abdul Aziz (99-101 H). Dia terkenal karena kebijakan dan keadilan serta keberhasilannya dalam memajukan dan mensejahterakan masyarakat, termasuk keberhasilannya dalam penanganan zakat yang ditujukan untuk mengentaskan kemiskinan, sehingga para petugas zakat mengalami kesulitan dalam mencari golongan fakir miskin yang membutuhkan harta zakat tersebut. Memang sifat amanah dan jujur ini akan menarik rizki dan kemudahan, sebaliknya sifat khianat dan tidak dapat dipercaya, akan menyebabkan kefakiran dan kesulitan. Hal ini sebagaimana dikemukakan dalam sebuah hadits riwayat Imam Daelami, Rasulullah Saw. bersabda:

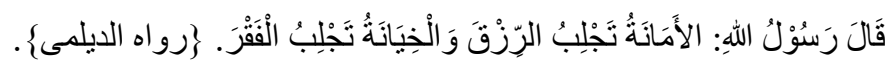

"Rassulullah Saw. bersabda: "Amanah itu akan menarik rizki, sedangkan khianat itu akan menarik kefakiran”. (HR. Imam Daelmaiy).

Keempat, Mengerti dan memahami hukum-hukum zakat yang menyebabkan ia mampu melakukan sosialisasi segala sesuatu yang berkaitan dengan zakat kepada masyarakat. Dengan pengetahuan tentang zakat yang reltif memadai, para amil zakat diharapkan terbebas dari kesalahan dan kekeliruan yang diakibatkan dari kebodohannya pada masalah zakat tersebut. 
Pengetahuan yang memadai tentang zakat inipun akan mengundang kepercayaan dari masyarakat.

Kelima, Memiliki kemampuan untuk melaksanakan tugas dengan sebaik-baiknya. Amanah dan jujur merupakan syarat yang sangat penting, akan tetapi juga harus ditunjang oleh kemampuan dalam melaksanakan tugas. Perpaduan antara amanah dan kemampuan inilah yang akan menghasilkan kinerja yang optimal.

Keenam, Syarat yang tidak kalah pentingnya, adalah kesungguhan amil zakat dalam melaksanakan tugasnya. Amil zakat yang baik adalah amil zakat yang full-time dalam melaksanakan tugasnya, tidak asal-asalan dan tidak pula sambilan. Banyaknya amil zakat yang sambilan dalam masyarakat kita menyebabkan amil zakat tersebut pasif dan hanya menunggu kedatangan muzakki untuk membayarkan zakatnaya atau infaqnya. Dan sebagian besar adalah bekerja pada bulan Ramadhan saja. Kondisi semacam ini harus segera dihentikan dan diganti dengan amil-amil yang serius, sungguh-sungguh dan menjadikan pekerjaan amil zakat sebagai pilihan hidupnya. Insya Allah, jika ditekuni akan menyebabkan amil zakat tersebut menjadi besar dan dipercaya oleh masyarakat. ${ }^{32}$

\section{Urgensi Lembaga Pengelola Zakat}

Pengelolaan zakat oleh lembaga pengelola zakat, apalagi yang mempunyai kekuatan hukum formal, akan memiliki beberapa keuntungan, antara lain:

Pertama, untuk menjamin kepastian dan disiplin pembayar zakat.

Kedua, untuk menjaga perasaan rendah diri para mustahiq zakat apabila berhadapan langsung untuk menerima zakat dari para muzakki.

Ketiga, untuk mencapai efisien dan efektivitas, serta sasaran yang tepat dalam penggunaan harta zakat menurut skala prioritas yang ada pada suatu tempat titik.

Keempat, untuk memperlihatkan syiar Islam dalam semangat penyelenggaraan pemerintahan yang islami. Sebaliknya, jika zakat diserahkan langsung dari muzakki kepada mustahiq, meskipun secara

${ }^{32}$ Halim, Abdul, Mengapa Zakat disyariatkan, MS2, Bandung, 2001 
hukum syari'ah adalah syah, akan tetapi bisa mengakibatkan terabaikannya hal-hal di atas, juga hikmah dan fungsi zakat, yang berkaitan dengan kesejahteraan umat akan sulit diwujudkan.

Di Indonesia, pengelolalan zakat yang telah diatur berdasarkan UU. No. 38 tahun 1999, tentang pengelolaan zakat dengan keputusan Menteri Agama (KMA) No. 581 tahun 1999, tentang pelaksanaan UU. No. 38 tahun 1999 dan keputusan Direktur Jenderal Bimbingan Masyarakat Islam dan Urusan Haji No. D/291 tahun 2000, tentang pedoman teknis pengelolaan zakat. ${ }^{33}$ Dalam UU. No. 38 tahun 1999, tentang pengelolaan zakat Bab II pasal 5 dikemukakan bahwa pengelolaan zakat bertujuan:

1. Meningkatkan pelayanan bagi masyarakat dalam menunaikan zakat sesuai dengan tuntunan agama.

2. Meningkatkan fungsi dan peran pranata keagamaan dalam upaya mewujudkan kesejahteraan masyarakat dan keadilan sosial.

3. Meningkatkan hasil guna dan daya guna zakat.

Pentingnya keberadaan lembaga pengelola zakat ini dengan para amilnya, karena mempunyai tugas yang sangat strategis dalam melaksanakan tugas dan kewajibannya yang berhubungan dengan pengaturan zakat, diantaranya pendataan orang-orang yang wajib zakat dan macam zakat yang diwajibkan kepadanya, juga besar harta yang wajib dizakati, kemudian mengetahui para mustahik zakat jumlah dan kebutuhan mereka ${ }^{34}$.

\section{Struktur Organisasi dan Kepengurusan BAZIS}

Undang-undang RI Nomor 38 tahun 1999 tentang Pengelolaan Zakat Bab III pasal 6 dan pasal 7 menyatakan bahwa lembaga pengelola zakat di Indonesia terdiri dari dua macam, yaitu Badan Amil Zakat (BAZ) dan Lembaga Amil Zakat (LAZ). Badan Amil Zakat dibentuk oleh pemerintah, sedangkan Lembaga Amil Zakat didirikan oleh masyarakat. Dalam buku Dalam buku petunjuk teknis pengelolaan zakat yang dikeluarkan oleh Institut Manajemen Zakat (2001) dikemukakan susunan organisasi lembaga pengelola zakat seperti Badan Amil Zakat sebagai berikut:

${ }^{33}$ Hafidhuddin, Didin, Zakat Dalam Perekonomian Modern, Gema Insani, Jakarta, 2002, hlm 127

${ }^{34}$ Qardhawi, Yusuf. Hukum Zakat, litera antarNusa, Jakarta 2004. Hlm. 546 


\section{Susunan Organisasi Badan Amil Zakat}

- Badan Amil Zakat terdiri dari Dewan Pertimbangan, Komisi Pengawas dan Badan Pelaksana.

- Dewan Pertimbangan sebagaimana dimaksud pada ayat (1) meliputi unsur ketua, sekertaris dan anggota.

O Komisi Pengawas sebagaimana dimaksud ayat (1) meliputi unsur ketua, sekertaris dan anggota.

- Badan Pelaksana sbeagaimana dimaksud pada ayat (1) meliputi unsur ketua, sekertaris, bagian keuangan, bagian pengumpulan, bagian pendistribusian dan pendayagunaan.

- Anggota pengurus Badan Amil Zakat terdiri atas unsur masyarakat dan unsur pemerintah. Unsur masyarakat terdiri atas unsur ulama, kaum cendekia, tokoh masyarakat, tenaga profesional dan lembaga pendidikan yang terkait. ${ }^{35}$

\section{Fungsi dan Tugas Badan Amil Zakat Daerah Kabupaten Bogor Dalam} Mengelola Zakat Mal dan Zakat Profesi

1. Fungsi dan Tugas Pokok Pengurus Badan Amil Zakat

a. Dewan Pertimbangan

1) Fungsi

Memberikan pertimbangan, fatwa, saran, dan rekomendasi kepada Badan Pelaksana dan Komisi Pengawas dalam Pengelolaan Badan Amil Zakat, meliputi aspek syari'ah dan aspek manajerial.

2) Tugas Pokok

$\Rightarrow$ Memberikan garis-garis kebijakan umum Badan Amil Zakat.

$\Rightarrow$ Mengesahkan rencana kerja dari Badan Pelaksana dan Komisi Pengawas.

${ }^{35}$ Hafidhuddin, Didin, Zakat Dalam Perekonomian Modern, Gema Insani, Jakarta, 2002, hlm 130 
$\Rightarrow$ Mengeluarkan fatwa syari'ah baik diminta maupun tidak berkaitan dengan hukum zakat yang wajib diikuti oleh pengelola Badan Amil Zakat.

$\Rightarrow$ Memberikan pertimbangan, saran dan rekomendasi kepada Badan Pelaksana dan Komisi Pengawas baik diminta maupun tidak.

$\Rightarrow$ Memberikan persetujuan atas laporan tahunan hasil kerja Badan Pelaksana dan Komisi Pengawas.

$\Rightarrow$ Menunjuk Akuntan Publik.

b. Komisi Pengawas

1) Fungsi

Sebagai pengawas internal lembaga atas operasional kegiatan yang dilaksanakan Badan Pelaksana.

2) Tugas Pokok

$\Rightarrow$ Mengawasi pelaksanaan rencana kerja yang telah disahkan.

$\Rightarrow$ Mengawasi pelaksanaan kebijakan-kebijakan yang telah ditetapkan Dewan Pertimbangan.

$\Rightarrow$ Mengawasi operasional kegiatan yang dilaksanakan Badan Pelaksana, yang mencakup pengumpulan, pendistribusian dan pendayagunaan.

$\Rightarrow$ Melakukan pemeriksaan operasional dan pemeriksaan syari'ah.

c. Badan Pelaksana

1) Fungsi

Sebagai pelaksana pengelolaan zakat.

2) Tugas Pokok

$\Rightarrow$ Membuat rencana kerja.

$\Rightarrow$ Melaksanakan operasional pengelolaan zakat sesuai rencana kerja yang telah disahkan dan sesuai dengan kebijakan yang telah ditetapkan. 
$\Rightarrow$ Menyusun laporan tahunan.

$\Rightarrow$ Menyampaikan laporan pertanggungjawaban kepada pemerintah.

$\Rightarrow$ Bertindak dan bertanggung jawab untuk dan atas nama Badan/Lembaga Amil Zakat ke dalam maupun ke luar.

Salah satu tugas penting lain dari lembaga pengelola zakat adalah melakukan sosialisasi tentang zakat kepada masyarakat secara terus-menerus dan berkesinambungan, melalui berbagai forum dan media, seperti khutbah Jum'at, majelis ta'lim, seminar, diskusi dan lokakarya, melalui media surat kabar, majalah, radio, internet maupun televisi. Dengan sosialisasi yang baik dan optimal, diharapkan masyarakat muzakki akan semakin sadar untuk membayar zakat melalui lembaga zakat yang kuat, amanah dan terpercaya. Materi sosialisasi antara lain berkaitan dengan kewajiban zakat, hikmah dan fungsinya, harta benda yang wajib dikeluarkan zakatnya, cara menghitung zakat yang mudah, serta cara menyalurkannya. Dan sejalan dengan UU No. 17/2000 tentang perubahan ketiga UU No. 7/1983 tentang pajak penghasilan, maka kaitan antara zakat dengan pajak ini perlu juga disosialisasikan kepada masyarakat. ${ }^{36}$

\section{Sasaran dan Tujuan Intruksi Bupati Tentang Zakat Profesi di Lingkungan Pemerintahan Kabupaten Bogor}

Secara umum instruksi bupati ini dikeluarkan untuk memberikan kemudahan pelayanan bagi muzakki dalam menunaikan kewajiban zakatnya dan meningkatkan kesejahteraan mustahik sekaligus meringankan beban Pemerintah dalam menanggulangi tingkat kemiskinan, maka bupati bogor merasa perlu mengeluarkan intruksi ini bagi pegawai yang berada dilingkungan pemerintahannya untuk membayarkan zakat profesi melalui badan amil zakat yang ada atau yang telah dibentuk oleh pemerintahan kabupaten Bogor.

Instruksi bupati ini sesuai dengan Undang-undang Nomor 14 tahun 1950 tentang Pemerintahan Daerah Kabupaten dalam Lingkungan Jawa Barat. Undang-undang Nomor 38 Tahun 1999 tentang Pengelolaan Zakat dalam

\footnotetext{
${ }^{36}$ Hafidhuddin, Didin, Zakat Dalam Perekonomian Modern, Gema Insani, Jakarta, 2002,
} hlm 132 
lembaran Negara Repulik Indonesia Tahun 1999. Undang-undang Nomor 32 Tahun 2004 tentang Pemerintahan Daerah, sebagaimana telah diubah dengan Undang-undang Nomor 8 Tahun 2005 tentang Penetapan Peraturan Pemerintahan. Keputusan gubernur Jawa Barat Nomor 73 tahun 2001 tentang Pengelolaan Zakat dan Pengurus Badan Amil Zakat (BAZ) Provinsi Jawa Barat. Peraturan Bupati Bogor Nomor 3 Tahun 2004 tentang Pengelolaan Zakat Infak dan Shodaqoh dan keputusan Bupati Bogor Nomor 451.12/Kpts/Huk/2008 tentang Pembentukan Badan Amil Zakat, Infaq dan Shadaqoh (BAZIS) Kabupaten Bogor masa bakti 2008-2011.

Mengingat semua dasar undang-undang dan keputusan pemerintahan Jawa Barat dan Kabupaten Bogor ini maka, Bupati Bogor yang saat itu masih dijabat oleh Bapak Agus Utara Efendi mengeluarkan instruksi tentang zakat profesi yang ditujukan kepada seluruh pegawai di Lingkungan Pemerintahan Kabupaten Bogor golongan III untuk membayarkan zakat profesinya sebesar 2,5 \% (dua koma lima perseratus) melalui BAZIS kabupaten Bogor. Intruksi ini merupakan perintah sekaligus peraturan yang dikeluarkan oleh Bupati kepada pegawai-pegawainya untuk dijalankan dan ditaati.. ${ }^{37}$

\section{Sasaran dan Tujuan Dikeluarkannya Instruksi Bupati Tentang Zakat Profesi}

Sasaran dikeluarkannya Instruksi Bupati Tentang Zakat Profesi tentunya sesuai dengan isi instruksi itu sendiri yaitu ditujukan kepada pegawai yang berada di Lingkungan Pemerintah Kabupaten Bogor golongan III yang berpenghasilan minimal Rp 2.000.000,- dengan besar zakat yang dikeluarkan sebanyak 2,5\% persen dari penghasilannya perbulan. Sedangkan tujuan dikeluarkannya instruksi Bupati ini adalah untuk meningkatkan kesejahteraan mustahik dan meringankan beban Pemerintah dalam menanggulangi tingkat kemiskinan yang ada di kabupaten bogor serta untuk memberikan pelayanan bagi muzakki dalam menunaikan kewajiban zakatnya melalui Lembaga Amil Zakat yang ada seperti BAZIS di Lingkungan Pemerintahan Kabupaten Bogor.

${ }^{3737}$ Instruksi Bupati Bogor Nomor 451.12/Kpts/Huk/2008 


\section{Dampak Intruksi Bupati Terhadap Kesadaran dan Kepatuhan Pegawai Pemkab dalam membayarkan Zakat Profesi.}

Setelah dikeluarkannya instruksi Bupati tentang zakat profesi yang ditujukan kepada pegawai golongan III di Lingkungan Pemerintahan Kabupaten Bogor maka penulis mencoba menkroscek ke kantor-kantor Dinas dan Instansi yang berada di Lingkungan Pemerintah Kabupaten Bogor mengenai tingkat kesadaran dan pengetahuan Pegawai mengenai instruksi Bupati tetang zakat profesi ini melalui penyebaran quesioner dan menggali informasi langsung kepada pegawai-pegawainya.

Dari 39 kantor Dinas dan Instansi yang ada, penulis mencoba mendatangi sekitar sepuluh kantor yang berada di lingkungan pemerintahan Kabupaten Bogor yang masing-masing kantor disebarkan quesioner kepada tiga sampai lima pegawainya sehingga penulis berhasil mengumpulkan 50 sampel dari hasil quesioner mengenai dampak instruksi Bupati tentang zakat profesi terhadap kesadaran pegawai dalam membayarkan zakat profesinya. Berikut hasil angket (quesioner) tersebut :

1. Pegawai cukup mengetahui tentang adanya instruksi Bupati tentang zakat profesi

2. Pegawai cukup mengerti apa itu zakat profesi

3. Sebagian pegawai sudah membayar zakat profesinya sebelum adanya instruksi bupati, dan sebagian pegawai lainnya membayarkan zakat profesinya setelah adanya instruksi bupati

4. Instruksi bupati cukup berdampak baik atas kesadaran pegawai dalam membayarkan zakat profesi

5. Sebagian pegawai membayarkan zakat Profesinya tidak sesuai dengan instruksi Bupati yaitu harus melalui BAZIS kabupaten Bogor.

Berikut ini prosentasi hasil angket (questioner) mengenai dampak instruksi Bupati terhadap pegawai pemerintahan kabupaten Bogor yang diberikan kepada 50 responden:

\section{Tabel 1}

Data 50 rensponden pegawai pemerintahan kabupaten Bogor

\begin{tabular}{|c|c|c|c|c|c|c|c|}
\hline $\begin{array}{c}\text { N } \\
\text { o }\end{array}$ & Nama & Dinas/Instansi & $\begin{array}{c}\text { Gol } \\
\text { ong }\end{array}$ & No & Nama & Dinas/Instansi & $\begin{array}{c}\text { Golon } \\
\text { gan }\end{array}$ \\
\hline
\end{tabular}




\begin{tabular}{|c|c|c|c|c|c|c|c|}
\hline & & & an & & & & \\
\hline 1 & Septian & Hukum Setda & IIIa & 26 & $\begin{array}{l}\text { Muharra } \\
\mathrm{m}\end{array}$ & komunikasi & IIIa \\
\hline 2 & Edi & Hukum Setda & IIIa & 27 & Zubaidah & Koperasi & IIIa \\
\hline 3 & Devi & Koperasi & $\mathrm{IIIb}$ & 28 & Melyani & Perternakan & III \\
\hline 4 & Asep & Hukum Setda & $\mathrm{IIIb}$ & 29 & Ari R & Perternakan & IIIa \\
\hline 5 & Abdul & Keuangan & III & 30 & Asih & Perikanan & IIIa \\
\hline 6 & Poppi & Keuangan & III & 31 & Diki & komunikasi & IIIa \\
\hline 7 & Caesar P & Hukum Setda & $\mathrm{IIIlb}$ & 32 & Sukarna & Komunikasi & III \\
\hline 8 & Hanny S & Hukum Setda & III & 33 & $\mathrm{TP}$ & $\begin{array}{l}\text { Kependuduka } \\
\mathrm{n}\end{array}$ & IIIa \\
\hline 9 & Ade Imn & Disdik & IIIa & 34 & Budi & $\begin{array}{l}\text { Kependuduka } \\
\mathrm{n}\end{array}$ & IIIa \\
\hline 10 & Nima K & Disdik & III & 35 & Neneng & $\begin{array}{l}\text { Kependuduka } \\
\mathrm{n}\end{array}$ & IIIa \\
\hline 11 & Yani R & Setda & IIIa & 36 & Muhidin & $\begin{array}{l}\text { Kependuduka } \\
\mathrm{n}\end{array}$ & III \\
\hline 12 & Masgun & Setda & III & 37 & Tedi & Perindustrian & IIIa \\
\hline 13 & Yedi m & Orgnsasi & IIIa & 38 & Dn & Perindustrian & $\mathrm{IIIb}$ \\
\hline 14 & Linda & Orgnsasi & IIIa & 39 & Regina & Perindustrian & III \\
\hline 15 & Yanuar & Orgnsasi & III & 40 & Hasmi S & Pertanian & IIIa \\
\hline 16 & Farid & Perekonomian & IIIa & 41 & Asep M & Dishut & $\mathrm{IIIlb}$ \\
\hline 17 & Wahyu & Perekonomian & $\mathrm{IIIlb}$ & 42 & Ajeng & Dishut & III \\
\hline 18 & Heni & Organisasi & III & 43 & Tri & Sosial & IIIa \\
\hline 19 & Ifan & Kominfo & IIIa & 44 & Indriyani & Sosial & IIIa \\
\hline 20 & Dedeh & Kominfo & III & 45 & Ririn & Dishut & III \\
\hline 21 & Lilik & Kominfo & IIIa & 46 & Fahrullah & Dishut & IIIa \\
\hline 22 & Deddi & Humas & III & 47 & Dewi & Sosial & III \\
\hline 23 & Roby R & Humas & IIIa & 48 & Iis & Kepegawaian & IIIa \\
\hline 24 & Eka & Humas & IIIa & 49 & Ridwan & Kepegawaian & III \\
\hline
\end{tabular}




\begin{tabular}{|l|l|l|l|l|l|l|l|}
\hline 25 & Cecep & Pertanian & III & 50 & Firman & Kepegawaian & III \\
\hline
\end{tabular}

Tabel 2

Kuantifikasi nilai prosentasi hasil angket

\begin{tabular}{|c|l|c|c|}
\hline \multirow{2}{*}{ No } & \multicolumn{1}{|c|}{$\begin{array}{c}\text { Nilai } \\
\text { Kuantifikasi }\end{array}$} & Frekuensi & Prosentasi (\%) \\
\hline \multirow{2}{*}{1} & Kurang & $10-20$ & $40 \%$ \\
\cline { 2 - 4 } & Cukup & $20-30$ & $60 \%$ \\
\cline { 2 - 4 } & Baik & $30-40$ & $80 \%$ \\
\hline \multirow{2}{*}{} & Sangat Baik & $40-50$ & $100 \%$ \\
\hline \multicolumn{2}{|c|}{ Jumlah } & $\mathbf{5 0}$ & $\mathbf{1 0 0} \%$ \\
\hline
\end{tabular}

\section{Tabel 3}

Pengetahuan pegawai terhadap adanya Instruksi Bupati tentang Zakat Profesi

\begin{tabular}{|c|l|c|c|}
\hline \multirow{2}{*}{ No } & $\begin{array}{c}\text { Alternatif } \\
\text { Jawaban }\end{array}$ & Frekuensi & Prosentasi (\%) \\
\hline \multirow{2}{*}{1} & Ya & 39 & $78 \%$ \\
\cline { 2 - 4 } & Tidak & 9 & $18 \%$ \\
\cline { 2 - 4 } & Ragu-ragu & 2 & $4 \%$ \\
\hline \multicolumn{2}{|c|}{ Jumlah } & $\mathbf{5 0}$ & $\mathbf{1 0 0} \%$ \\
\hline
\end{tabular}

Dari data diatas, dapat diketahui bahwa para pegawai cukup tahu dengan baik akan adanya instruksi bupati tentang zakat profesi yang ditujukan kepada pegawai golongan III yang berada dilingkungan pemerintahan kabupaten Bogor. Hal ini dapat dilihat dari hasil angket yang diberikan kepada sebagian pegawai di beberapa instansi dan dinas pemerintahan sebagai responden yang menjawab ya sebanyak $78 \%$ dan yang menjawab tidak $18 \%$ dan yang ragu-ragu adanya instruksi bupati sebanyak $4 \%$.

\section{Tabel 4}


Ketika ditanya tentang apakah Bapak/Ibu tahu apa itu zakat profesi, maka para pegawai menjawab sebagai berikut :

\begin{tabular}{|c|l|c|c|}
\hline \multirow{2}{*}{ No } & \multicolumn{1}{|c|}{$\begin{array}{c}\text { Alternatif } \\
\text { Jawaban }\end{array}$} & Frekuensi & Prosentasi (\%) \\
\hline \multirow{2}{*}{2} & Ya & 38 & $76 \%$ \\
\cline { 2 - 4 } & Tidak & 7 & $14 \%$ \\
\cline { 2 - 4 } & Ragu-ragu & 5 & $10 \%$ \\
\hline \multicolumn{2}{|c|}{ Jumlah } & $\mathbf{5 0}$ & $\mathbf{1 0 0} \%$ \\
\hline
\end{tabular}

Dari table diatas, dapat diketahui bahwa para pegawai cukup tahu atau mengerti tetang apa itu zakat profesi, karena $76 \%$ persen diantaranya menjawab ya dan $14 \%$ menjawab tidak mengerti, kemudian yang ragu-ragu mengerti atau tidak $10 \%$ dari responden.

\section{Tabel 5}

Kemungkinan pegawai membayarkan zakat profesi sebelum adanya instruksi Bupati.

\begin{tabular}{|c|l|c|c|}
\hline \multirow{2}{*}{ No } & \multicolumn{1}{|c|}{$\begin{array}{c}\text { Alternatif } \\
\text { Jawaban }\end{array}$} & Frekuensi & Prosentasi (\%) \\
\hline \multirow{2}{*}{3} & Ya & 25 & $50 \%$ \\
\cline { 2 - 4 } & Tidak & 21 & $42 \%$ \\
\cline { 2 - 4 } & Ragu-ragu & 4 & $8 \%$ \\
\hline \multicolumn{2}{|c|}{ Jumlah } & $\mathbf{5 0}$ & $\mathbf{1 0 0 \%}$ \\
\hline
\end{tabular}

Dari data diatas dapat diketahu bahwa sebagian pegawai sudah pernah membayarkan zakat profesinya sebelum dikeluarkan instruksi Bupati yaitu sebanyak $50 \%$ dan sebagian yang lainnya $42 \%$ belum pernah dan sisanya $8 \%$ ragu-ragu.

\section{Tabel 6}

Ketika ditanya apakah Bapak/Ibu membayarkan zakat profesinya setelah adanya instruksi Bupati maka jawabannya sebagai berikut :

\begin{tabular}{|c|c|c|c|}
\hline No & $\begin{array}{c}\text { Alternatif } \\
\text { Jawaban }\end{array}$ & Frekuensi & Prosentasi (\%) \\
\hline 4 & $\mathrm{Ya}$ & 28 & $56 \%$ \\
\hline
\end{tabular}




\begin{tabular}{|c|l|c|c|}
\hline \multirow{2}{*}{} & Tidak & 20 & $40 \%$ \\
\cline { 2 - 4 } & Ragu-ragu & 2 & $4 \%$ \\
\hline \multicolumn{2}{|c|}{ Jumlah } & $\mathbf{5 0}$ & $\mathbf{1 0 0 \%}$ \\
\hline
\end{tabular}

Sebagian responden dari pegawai pemkab yaitu sebanyak 56\% membayarkan zakat profesinya setelah adanya instruksi Bupati tentang zakat profesi. Sedangkan sebagian lainnya $40 \%$ tidak terpengaruh dengan adanya instruksi bupati tersebut dan sisanya sebanyak $4 \%$ menjawab ragu-ragu atau tidak tahu.

\section{Tabel 7}

Ketika responden ditanya apakah instruksi Bupati berdampak terhadap kesadaran pegawai dalam membayarkan zakat profesi? maka jawabannya adalah :

\begin{tabular}{|c|l|c|c|}
\hline No & $\begin{array}{c}\text { Alternatif } \\
\text { Jawaban }\end{array}$ & Frekuensi & Prosentasi (\%) \\
\hline \multirow{2}{*}{5} & Ya & 37 & $74 \%$ \\
\cline { 2 - 4 } & Tidak & 5 & $10 \%$ \\
\cline { 2 - 4 } & Ragu-ragu & 8 & $16 \%$ \\
\hline \multicolumn{2}{|c|}{ Jumlah } & $\mathbf{5 0}$ & $\mathbf{1 0 0} \%$ \\
\hline
\end{tabular}

Dari keterangan table di atas maka dapat diketahui bahwa instruksi bupati cukup berdampak terhadap kesadaran pegawai dalam membayarkan zakat profesi sebagaimana yang telah di instruksikan Bupati dengan sebanyak $74 \%$ menjawab ya dan $10 \%$ menjawab tidak, kemudian yang ragu $16 \%$.

\section{Tabel 8}

Dan apakah para pegawai membayarkan zakat profesi sudah sesuai dengan instruksi bupati yaitu membayarkan zakatnya ke BAZIS maka jawabannya antara lain :

\begin{tabular}{|c|l|c|c|}
\hline No & \multicolumn{1}{|c|}{$\begin{array}{c}\text { Alternatif } \\
\text { Jawaban }\end{array}$} & Frekuensi & Prosentasi (\%) \\
\hline \multirow{2}{*}{6} & Ya & 23 & $46 \%$ \\
\cline { 2 - 4 } & Tidak & 21 & $42 \%$ \\
\cline { 2 - 4 } & Ragu-ragu & 6 & $12 \%$ \\
\hline
\end{tabular}




\begin{tabular}{|c|c|c|}
\hline Jumlah & 50 & $100 \%$ \\
\hline
\end{tabular}

Dari tabel tersebut dapat diketahui bahwa para pegawai hampir setengahnya telah membayarkan zakatnya sesuai dengan instruksi bupati yaitu sebanyak $46 \%$, dan sebagiannya lagi sebanyak $42 \%$ tidak membayarkan zakatnya sesuai dengan intruksi Bupati sedangkan sisanya 12\% menjawab ragu-ragu atau tidak tahu. Jadi secara keseluruhan Instruksi Bupati cukup berdampak terhadap pengetahuan, kesadaran dan kepatuhan pegawai dalam membayarkan zakat profesinya di BAZIS kabupaten Bogor dengan melihat rekapitulasi persentasi dari beberapa pertanyaan yang diajukan oleh penulis.

\section{Tabel 9}

Rekapitulasi dari Persentasi hasil angket (questioner)

\begin{tabular}{|c|c|c|c|c|c|}
\hline \multirow{2}{*}{$\begin{array}{c}\text { No } \\
\text { Soal }\end{array}$} & \multicolumn{3}{|c|}{ Pilihan jawaban } & \multirow{2}{*}{ Jumlah } & keterangan \\
\cline { 2 - 4 } & Ya & Tidak & Ragu-ragu & & \\
\hline $\mathbf{1}$ & $78 \%$ & $18 \%$ & $4 \%$ & $100 \%$ & 50 Resp \\
\hline $\mathbf{2}$ & $76 \%$ & $14 \%$ & $10 \%$ & $100 \%$ & 50 Resp \\
\hline $\mathbf{3}$ & $50 \%$ & $42 \%$ & $8 \%$ & $100 \%$ & 50 Resp \\
\hline $\mathbf{4}$ & $56 \%$ & $40 \%$ & $4 \%$ & $100 \%$ & 50 Resp \\
\hline $\mathbf{5}$ & $74 \%$ & $10 \%$ & $16 \%$ & $100 \%$ & 50 Resp \\
\hline $\mathbf{6}$ & $46 \%$ & $42 \%$ & $12 \%$ & $100 \%$ & 50 Resp \\
\hline & & & & & \\
\hline Jumlah & $374: 6$ & $172: 6$ & $54: 6$ & & \\
\hline & $\mathbf{6 2 , 3} \%$ & $\mathbf{2 8 , 7} \%$ & $\mathbf{9 \%}$ & $\mathbf{1 0 0} \%$ & 50 Resp \\
\hline
\end{tabular}

Jadi dampak positif secara keseluruhan instruksi bupati terhadap kesadaran pegawainya dalam membayarkan zakat profesi sekitar 62,3\% dari responden, sedangan $28,7 \%$ dari pegawai tidak merasakan dampaknya dan $9 \%$ merasa ragu-ragu atau tidak tahu.

\section{Dampak Intruksi Bupati Terhadap Pengelolaan Zakat Profesi di BAZIS Kabupaten Bogor}

Dengan dikeluarkannya instruksi Bupati tentang zakat profesi terhadap pegawai di lingkungan Pemerintahan Kabupaten Bogor No 
451.5/1/Inst/Huk/2008, menambah amanah yang diemban BAZIS untuk memaksimalkan pendapatan dana zakat khususnya dari pegawai kabupaten bogor, dan instruksi bupati ini secara tidak langsung berdampak terhadap Pengelolaan Zakat di BAZIS kabupaten Bogor antara lain :

1. Pendataan terhadap para Muzakki; Muzakki yang dmaksud adalah Pegawai golongan III yang ada di beberapa Instansi di Lingkungan Pemerintahan Kabupaten Bogor yang pendapatannya sudah mencapai nisab atau batasan untuk mengeluarkan zakat profesinya.

2. Pendataan Para Mustahik; Pendataan mustahik dilakukan agar mendapatkan kejelasan mengenai data yang akurat mengenai jumlah mustahik di kabupaten Bogor. BAZIS biasanya meminta data mengenai jumlah keluarga miskin dan dhuafa dikantor Dinas social Kabupaten Bogor, atau melalui unit Pengumpulan Zakat (UPZ) ditingkat desa atau kecamatan yang tersebar diwilayah kabupaten Bogor. Dari data yang diperoleh tercatat jumlah penduduk wilayah Kabupaten Bogor mencapai 4.215.436 orang jiwa dengan jumlah kepala keluarga (KK) 1.041.901, sedangkan yang termasuk katagori keluarga miskin (Gakin) berjumlah 536.400 jiwa.

3. Melakukan Sosialisasi, Promosi dan Publikasi; Promosi dan Publikasi dilakukan dengan maksud agar para muzakki kenal dan lebih percaya dengan Badan Amil Zakat, Infaq dan Shadaqah (BAZIS) kabupaten Bogor, sehingga pengumpulan dana Zakat, infaq dan shadaqah dapat lebih maksimal secara struktur organisasi, program kerja dan personalnya. Kegiatan ini biasanya dilakukan dengan cara melalui berabgai media seperti brosur, spanduk, billboard, dan media cetak Koran dan bulletin yang bekerjasama dengan Majelis Ulama Indonesi (MUI) kabupaten Bogor. Untuk menjaring dana dari masyarakat dan pegawai pemkab selain melakukan sosialisasi dan promosi, BAZIS juga melakukan beberapa upaya yang berbentuk kebijakan untuk mengumpulkan dana zakat antara lain: Melakukan seruan untuk pengumpulan zakat, infaq dan shadaqah, Pengiriman surat kepada seluruh instansi dan kepala dinas yang berada di wilayah Kabupaten Bogor, Muzakki secara langsung datang ke BAZ, Melalui Unit Pengumpulan Zakat (UPZ), Melalui Pos atau Bank, Melalui pemotongan gaji, Melalui jemput Bola.

Walau sudah merasa maksimal BAZIS melakukan sosialisasi dan publikasi untuk menarik minat para muzakki untuk membayarkan zakatnya tapi masih perlu terobosan baru untuk meningkatkan pendapatan BAZIS. 
Salah satunya memaksimalkan sosialisasi instruksi bupati tentang zakat profesi kepada pegawai-pegawai yang ada dilingkungan pemerintahan Kabupaten bogor. Karena penulis menemukan dari hasil angket yang diberikan kepada sebagian pegawai, belum merasakan sosialisasi yang maksimal dari BAZIS sehingga banyak daripada pegawai membayarkan zakatnya tidak melalui BAZIS Kabupaten Bogor tetapi kepada lembaga amil zakat lainnya. Berikut hasil angket (questioner) yang telah didapatkan penulis:

\section{Tabel 10}

Mengenai pembayaran zakat ke BAZIS responden menjawab :

\begin{tabular}{|c|l|c|c|}
\hline \multirow{2}{*}{ No } & $\begin{array}{c}\text { Alternatif } \\
\text { Jawaban }\end{array}$ & Frekuensi & Prosentasi (\%) \\
\hline \multirow{2}{*}{1} & Ya & 19 & $38 \%$ \\
\cline { 2 - 4 } & Tidak & 29 & $58 \%$ \\
\cline { 2 - 4 } & Ragu-ragu & 2 & $4 \%$ \\
\hline \multicolumn{2}{|c|}{ Jumlah } & $\mathbf{5 0}$ & $\mathbf{1 0 0} \%$ \\
\hline
\end{tabular}

Dari hasil angket diatas dapat kita simpulkan bahwa banyak dari pegawai tidak membayarkan zakat profesinya di BAZIS sebanyak $58 \%$ dari responden, dan yang membayarkan zakat profesinya ke BAZIS hanya $38 \%$ saja dan sisanya $4 \%$ menjawab ragu-ragu atau tidak tahu.

\section{Tabel 11}

Kemudian ditanya kenapa tidak membayarkan zakat profesinya ke BAZIS responden menjawab sebagai berikut :

\begin{tabular}{|c|l|c|c|}
\hline No & Alternatif Jawaban & Frekuensi & Prosentasi (\%) \\
\hline \multirow{2}{*}{8} & Kurang Percaya & 4 & $14 \%$ \\
\cline { 2 - 4 } & Kurang Sosialisasi & 16 & $56 \%$ \\
\cline { 2 - 4 } & Tidak Tahu & 9 & $30 \%$ \\
\hline \multicolumn{2}{|c|}{ Jumlah } & $\mathbf{2 9}$ & $\mathbf{1 0 0} \%$ \\
\hline
\end{tabular}

Jadi lebih dari setengahnya atau sekitar 56\% responden yang tidak membayarkan zakatnya di BAZIS menjawab karena kurang adanya sosialisasi pembayaran zakat terhadap pegawai, 30\% menjawab tidak tahu dan $14 \%$ nya menjawab kurang percaya. 
Ini hasilnya sama dengan pertanyaan penulis berikutnya yaitu apakah responden sudah merasakan sosialisasi yang maksimal dari BAZIS? Jawaban adalah:

Tabel 12

\begin{tabular}{|c|l|c|c|}
\hline No & $\begin{array}{c}\text { Alternatif } \\
\text { Jawaban }\end{array}$ & Frekuensi & Prosentasi (\%) \\
\hline \multirow{2}{*}{1} & Sudah & 7 & $14 \%$ \\
\cline { 2 - 4 } & Belum & 38 & $76 \%$ \\
\cline { 2 - 4 } & Ragu-ragu & 5 & $10 \%$ \\
\hline \multicolumn{2}{|c|}{ Jumlah } & $\mathbf{5 0}$ & $\mathbf{1 0 0} \%$ \\
\hline
\end{tabular}

$76 \%$ dari responden menjawab belum merasakan sosialisasi yang maksimal dari BAZIS dalam pembayaran zakat profesi, $14 \%$ menjawab sudah dan 10\% menjawab ragu-ragu. Ini wajar terjadi karena sosialisasi yang belum merata dari BAZIS terhadap para pegawai dan instansi-instansi yang ada di lingkungan kabupaten bogor yang berjumlah lebih dari tiga puluh sembilan kantor, hanya tiga puluh tujuh kantor saja yang mendapatkan sosialisasi tentang zakat profesi secara langsung.

Mengenai hal ini penulis mencoba menggali informasi kepengurus BAZIS berkaitan dengan sosialisasi yang dilakukan oleh BAZIS, dari informasi yang penulis dapatkan bahwa sudah semua instansi Pemerintahan Kabupaten Bogor mendapatkan sosialisasi dari BAZIS. Permasalahannya adalah ketika BAZIS mengadakan sosialisasi banyak dari kepala dinas dan istansi tidak datang dan mewakilkan kepada bawahannya, akibatnya informasi yang diberikan BAZIS tidak langsung dan merata didapatkan oleh semua pegawai Pemerintahan KAbupaten Bogor.

Berikut daftar instansi yang menerima Sosialisasi Zakat Profesi dari BAZIS di Pemerintahan Kabupaten Bogor sebelum dan sesudah dikeluarkannya instruksi Bupati tentang zakat profesi.

Tabel 13

\begin{tabular}{|l|l|l|l|}
\hline No & \multicolumn{1}{|c|}{ Nama Instansi dan Dinas } & $\begin{array}{l}\text { Sebelum } \\
\text { Instruksi (2008) }\end{array}$ & $\begin{array}{l}\text { Setelah } \\
\text { Instruksi (2009) }\end{array}$ \\
\hline 1 & Bagian Hukum Setda & Belum & $\begin{array}{l}\text { Sudah } \\
\text { Menerima }\end{array}$ \\
\hline
\end{tabular}




\begin{tabular}{|c|c|c|c|}
\hline 2 & Bagian Keuangan Setda & Belum & $\begin{array}{l}\text { Sudah } \\
\text { Menerima }\end{array}$ \\
\hline 3 & Bagian Umum Setda & Belum & $\begin{array}{l}\text { Sudah } \\
\text { Menerima }\end{array}$ \\
\hline 4 & Bagian Pemerintahan Desa Setda & Belum & $\begin{array}{l}\text { Sudah } \\
\text { Menerima }\end{array}$ \\
\hline 5 & Bagian Organisasi Setda & Belum & $\begin{array}{l}\text { Sudah } \\
\text { Menerima }\end{array}$ \\
\hline 6 & Bagian Humas Setda & Belum & $\begin{array}{l}\text { Sudah } \\
\text { Menerima }\end{array}$ \\
\hline 7 & Bagian Perekonomian & Belum & $\begin{array}{l}\text { Sudah } \\
\text { Menerima }\end{array}$ \\
\hline 8 & Bagian Kepegawaian & Belum & $\begin{array}{l}\text { Sudah } \\
\text { Menerima }\end{array}$ \\
\hline 9 & Bagian Sosial & Belum & $\begin{array}{l}\text { Sudah } \\
\text { Menerima }\end{array}$ \\
\hline 10 & Dinas Parawisata & Sudah Menerima & $\begin{array}{l}\text { Sudah } \\
\text { Menerima }\end{array}$ \\
\hline 11 & Dinas Tenaga Kerja dan Trasmigrasi & Belum & $\begin{array}{l}\text { Sudah } \\
\text { Menerima }\end{array}$ \\
\hline 12 & Dinas Pendidikan & Belum & $\begin{array}{l}\text { Sudah } \\
\text { Menerima }\end{array}$ \\
\hline 13 & Dinas Pertanian dan Kehutanan & Sudah Menerima & $\begin{array}{l}\text { Sudah } \\
\text { Menerima }\end{array}$ \\
\hline 14 & Dinas Perternakan dan Perikanan & Sudah Menerima & $\begin{array}{l}\text { Sudah } \\
\text { Menerima }\end{array}$ \\
\hline 15 & $\begin{array}{l}\text { Dinas Kependudukan dan cacatan } \\
\text { Sipil }\end{array}$ & Sudah Menerima & $\begin{array}{l}\text { Sudah } \\
\text { Menerima }\end{array}$ \\
\hline 16 & Dinas Perhubungan & Sudah Menerima & $\begin{array}{l}\text { Sudah } \\
\text { Menerima }\end{array}$ \\
\hline 17 & $\begin{array}{l}\text { Dinas Tata ruang dan Lingkungan } \\
\text { Hidup }\end{array}$ & Sudah Menerima & $\begin{array}{l}\text { Sudah } \\
\text { Menerima }\end{array}$ \\
\hline 18 & Dinas Pertambangan & Sudah Menerima & Sudah \\
\hline
\end{tabular}




\begin{tabular}{|c|c|c|c|}
\hline & & & Menerima \\
\hline 19 & Dinas Kesehatan & Belum & $\begin{array}{l}\text { Sudah } \\
\text { Menerima }\end{array}$ \\
\hline 20 & Dinas Bina Marga & Belum & $\begin{array}{l}\text { Sudah } \\
\text { Menerima }\end{array}$ \\
\hline 21 & Dinas Cipta Karya & Sudah Menerima & $\begin{array}{l}\text { Sudah } \\
\text { Menerima }\end{array}$ \\
\hline 22 & $\begin{array}{l}\text { Dinas Perindustrian dan } \\
\text { Perdagangan }\end{array}$ & Sudah Menerima & $\begin{array}{l}\text { Sudah } \\
\text { Menerima }\end{array}$ \\
\hline 23 & Dinas Satpol PP & Belum & $\begin{array}{l}\text { Sudah } \\
\text { Menerima }\end{array}$ \\
\hline 24 & Dinas Pendapatan Daerah & Sudah Menerima & $\begin{array}{l}\text { Sudah } \\
\text { Menerima }\end{array}$ \\
\hline 25 & Bappeda & Belum & Belum \\
\hline 26 & Badan Pengawasan Daerah & Sudah Menerima & $\begin{array}{l}\text { Sudah } \\
\text { Menerima }\end{array}$ \\
\hline 27 & Badan Rumah sakit daerah cibinong & Sudah Menerima & $\begin{array}{l}\text { Sudah } \\
\text { Menerima }\end{array}$ \\
\hline 28 & Badan Diklat & Sudah Menerima & $\begin{array}{l}\text { Sudah } \\
\text { Menerima }\end{array}$ \\
\hline 29 & Kantor BPN & Belum & Belum \\
\hline 30 & Kantor Arsip dan Perpustakaan & Sudah Menerima & $\begin{array}{l}\text { Sudah } \\
\text { Menerima }\end{array}$ \\
\hline 31 & Kantor Koperasi dan UKM & Sudah Menerima & $\begin{array}{l}\text { Sudah } \\
\text { Menerima }\end{array}$ \\
\hline 32 & Kantor Pengadilan Agama & Sudah Menerima & $\begin{array}{l}\text { Sudah } \\
\text { Menerima }\end{array}$ \\
\hline 33 & Kantor Penanaman Modal & Sudah Menerima & $\begin{array}{l}\text { Sudah } \\
\text { Menerima }\end{array}$ \\
\hline 34 & Kantor Pelayanan Pajak & Sudah Menerima & $\begin{array}{l}\text { Sudah } \\
\text { Menerima }\end{array}$ \\
\hline 35 & Kantor Departemen Agama & Sudah Menerima & $\begin{array}{l}\text { Sudah } \\
\text { Menerima }\end{array}$ \\
\hline
\end{tabular}




\begin{tabular}{|l|l|l|l|}
\hline 36 & PDAM Tirta Kahuripan & Belum & $\begin{array}{l}\text { Sudah } \\
\text { Menerima }\end{array}$ \\
\hline 37 & PT. Pos dan Giro & Sudah Menerima & $\begin{array}{l}\text { Sudah } \\
\text { Menerima }\end{array}$ \\
\hline 38 & Polres Cibinong & Belum & $\begin{array}{l}\text { Sudah } \\
\text { Menerima }\end{array}$ \\
\hline 39 & BANK JABAR & Sudah Menerima & $\begin{array}{l}\text { Sudah } \\
\text { Menerima }\end{array}$ \\
\hline & Jumlah & Belum 19 Instansi & $\begin{array}{l}\text { Belum } \\
\text { Instansi } \\
\text { Sudah 20 instansi } \\
\text { Sudah } \\
\text { instansi }\end{array}$ \\
\hline
\end{tabular}

Dari data diatas menunjukkan bahwa instansi yang menerima sosialisasi dari BAZIS mengenai zakat profesi hanya setengahnya saja sebelum dikeluarkannya instruksi Bupati yaitu sebanyak 20 instansi dan 19 lainnya belum. Sedangkan setelah adanya instruksi Bupati yang sudah mendapatkan sosialisasi sebanyak 37 instansi dan yang belum 2 instansi. Ini mengindikasikan bahwa sosialisasi yang dilakukan BAZIS meningkat dari tahun sebelumnya. Jadi dapat penulis simpulkan bahwa instruksi bupati cukup berdampak terhadap peningkatan pengelolaan dan sosialisasi zakat profesi yang dilakukan BAZIS di Lingkungan Pemerintahan Kabupaten Bogor.

\section{Mekanisme pengumpulan dana zakat}

Badan Amil Zakat (BAZIS) Kabupaten Bogor mempunyai meknisme pengumpulan dari mulai tingkat desa, kecamatan sampai dengan tingkat Kabupaten. Dengan urutannya sebagai berikut :

1) Transfer Melalui Bank melalui rekening yang telah disediakan

2) Melalui BAZ unit masjid atau Dewan Kesejahteraan Masjid (DKM), dengan mengisi formulir pembayaran Zakat

3) Melalui kantor BAZ ditingkat Desa dan Kecamatan

4) Dengan dijemput oleh petugas atau kolektor BAZIS kabupaten Bogor. 
Dalam pengumpulan dana zakat, infaq dan shadaqah BAZIS kabupaten bogor hanya berwenang mengumpulkan dana zakat di instansi atau lembaga pemerintahan kabupaten bogor, dinas-dinas, perusahaanperusahaan daerah dan swasta. Adapun pengumpulan dana zakat dari masyarakat, maka BAZIS kecamatan dan kelurahanlah yang mempunyai tugas untuk menyetorkan dan melaporkan dana Zakat ke BAZIS tingkat kabupaten, begitu pula dengan BAZIS Kabupaten Bogor mempunyai kewajiban untuk melaporkan dana zakat ke BAZIS tingkat Provinsi.

\section{Tabel 13}

Pendapatan Zakat Profesi di BAZIS Kab Bogor dari tahun 2006-2008 atau sebelum dan sesudah dikeluarkannya Instruksi Bupati.

\begin{tabular}{|c|c|c|c|c|}
\hline No & Bulan & Tahun 2006 (Rp) & Tahun 2007 (Rp) & Tahun 2008 (Rp) \\
\hline 1 & Januari & 5.175 .000 & 10.070 .000 & 6.461 .500 \\
\hline 2 & Februari & 5.115 .000 & 10.070 .000 & 8.902 .800 \\
\hline 3 & Maret & 5.450 .000 & 11.820 .000 & 36.428 .400 \\
\hline 4 & April & 5.000 .000 & 1.032 .000 & 34.489 .000 \\
\hline 5 & Mei & 5.615 .000 & 29.749 .400 & 38.232 .200 \\
\hline 6 & Juni & 5.600 .000 & 15.391 .300 & 35.755 .000 \\
\hline 7 & Juli & 5.085 .000 & 17.488 .300 & 38.882 .500 \\
\hline 8 & Agustus & 5.408 .000 & 16.213 .700 & 35.736 .000 \\
\hline 9 & September & 2.288 .000 & 9.818 .800 & 62.814 .462 \\
\hline 10 & Oktober & 29.528 .525 & 29.490 .100 & 12.347 .700 \\
\hline 11 & November & 1.994 .000 & 7.736 .600 & 62.743 .395 \\
\hline 12 & Desember & 5.443 .000 & 11.088 .400 & 76.791 .927 \\
\hline \multicolumn{7}{|c|}{ Jumlah } & $\mathbf{1 0 2 . 7 1 2 . 3 7 5}$ & $\mathbf{1 6 9 . 9 6 8 . 6 0 0}$ & $\mathbf{4 4 9 . 5 8 4 . 8 8 4}$ \\
\hline
\end{tabular}

Dari data diatas diketahui bahwa terdapat perbedaan penerimaan zakat profesi dari tahun 2006 dan 2007 sebelum adanya instruksi Bupati, dan tahun 2008 setelah dikeluarkannya instruksi bupati tentang zakat profesi. Data ini dapat menjadi kesimpulan akan adanya dampak instruksi bupati terhadap pengelolaan dan pendapatan dana Zakat di BAZIS Kab. Bogor. Pendapatan Zakat profesi lebih banyak didapatkan melalui mekanisme pemotongan gaji dari kantor-kantor dinas, bukan dari pembayaran langsung 
oleh para pegawainya. Pengelolaan dan sosialisasi zakat yang dilakukan BAZIS selain karena menindak lanjuti instruksi bupati juga berdasarkan kinerja manajemen 'Amil zakat yang sudah ada aturan dan mekanisme tersendiri untuk mengumpulkan dana zakat walaupun masih perlu untuk ditingkatkan.

Berikut Rekapitulasi Penerimaan Dana ZIS sebelum dan sesudah dikeluarkannya instruksi Bupati :

\section{Tabel 14}

\begin{tabular}{|l|l|r|r|l|}
\hline No & \multicolumn{1}{|c|}{ Sumber Pendapatan } & \multicolumn{1}{c|}{$\begin{array}{c}\text { Tahun 2007 } \\
\mathbf{( R p )}\end{array}$} & \multicolumn{1}{c|}{$\begin{array}{c}\text { Tahun 2008 } \\
(\mathbf{R p})\end{array}$} & Ket \\
\hline 1 & Zakat Fitrah & 2.457 .000 & 1.255 .000 & \\
\hline 2 & Zakat Maal/Profesi & 169.968 .600 & 449.584 .884 & \\
\hline 3 & Infaq/Shadaqah & 268.192 .775 & 225.469 .700 & \\
\hline 4 & Jasa Bank & 1.855 .021 & 504.098 & \\
\hline 5 & Nisbah BSM/Bagi hasil & 1.834 .542 & 5.457 .871 & \\
\hline 6 & Angsuran Piutang & 74.150 .000 & 36.300 .00 & \\
\hline 7 & Bantuan Pemda & 200.000 .000 & 2.000 .000 & \\
\hline & Jumlah & $\mathbf{7 1 8 . 4 5 7 . 9 3 8}$ & $\mathbf{9 1 8 . 5 7 1 . 5 5 3}$ & \\
\hline
\end{tabular}

Data BAZIS 2008

\section{Meningkatkan pendistribusian Zakat, Infak dan Shadaqah BAZIS Kabupaten Bogor}

Sistem yang digunakan oleh BAZIS Kab. Bogor dalam pendistribusian dana ZIS menganut prinsip manfaat dan produktif yang berarti bahwa mustahik perorangan tidak saja menerima dana zakat, infaq dan shadaqah untuk dikonsumsi, tetapi juga diberi bimbingan dan modal usaha yang cukup agar mereka dapat hidup produktif dan mandiri. Oleh sebab itu pendistribusian dana zakat, infaq dan shadaqah dapat digolongkan dalam 4 (empat) bentuk, yaitu :

1) Konsumtif Produktif yaitu dibagikan kepada mustahik untuk dimanfatkan langsung untuk memenuhi kebutuhannya sehari-hari. Seperti zakat fitrah dan zakat maal untuk korban bencana alam 
2) Konsumtif kreatif yaitu zakat yang diwujudkan dalam bentuk lain dari barangnya semula, seperti diberikan dalam bentuk alat-alat sekolah, biaya perbaikan sekolah dan beasiswa.

3) Produktif Tradisional yaitu zakat yang diberikan dalam bentuk barang-barang yang produktif seperti pemberian barang untuk menciptakan usaha atau lapangan kerja.

4) Produktif Kreatif yaitu pendayaan zakat yang duwujudkan dalam bentuk permodalan baik untuk pembangunan proyek social atau membantu menambah modal pedagang atau usaha kecil.

Pengeluaran BAZIS dalam pendistribusian dana zakat juga menunjukan peningkatan sebelum dan sesudah adanya instruksi Bupati. Berikut total pengeluaran Dana ZIS dari tahun 2007 sampai tahun 2008.

Tabel 15

\begin{tabular}{|l|l|r|r|l|}
\hline No & \multicolumn{1}{|c|}{ BULAN } & Tahun 2007 (Rp) & \multicolumn{1}{c|}{$\begin{array}{c}\text { Tahun 2008 } \\
\text { (Rp) }\end{array}$} & \multicolumn{1}{c|}{ Ket } \\
\hline 1 & Januari & 9.757 .000 & 17.971 .500 & Pendistribusian \\
\hline 2 & Februari & 31.741 .750 & 7.867 .650 & Dislurkan untuk \\
\hline 3 & Maret & 26.107 .125 & 137.234 .600 & 1. Fakir miskin \\
\hline 4 & April & 17.071 .375 & 22.957 .800 & 2. Sabilillah \\
\hline 5 & Mei & 26.303 .475 & 66.873 .850 & 3. Ibnu sabil \\
\hline 6 & Juni & 18.234 .950 & 28.207 .000 & 4. gharimin \\
\hline 7 & Juli & 17.584 .825 & 79.790 .800 & 5. Mualllaf \\
\hline 8 & Agustus & 42.557 .550 & 35.296 .690 & 6. Amilin UPZ \\
\hline 9 & September & 21.051 .625 & 61.232 .800 & 7. Amilin BAZ \\
\hline 10 & Oktober & 57.821 .175 & 9.380 .860 & 8. Qordul Hasan \\
\hline 11 & November & 6.750 .725 & 24.692 .000 & 9. Hibah BMT \\
\hline 12 & Desember & 17.647 .725 & 117.667 .400 & 10. dll \\
\hline & Jumlah & $\mathbf{2 9 2 . 6 2 9 . 3 0 0}$ & $\mathbf{6 0 9 . 1 7 2 . 9 5 0}$ & \\
\hline
\end{tabular}

\section{Data BAZIS 2008}




\section{Mengurangi kendala dan hambatan BAZIS dalam menghimpun dana Zakat di Lingkungan Pemerintahan Kabupaten Bogor}

Ada beberapa kendala dan hambatan yang seringkali menghambat kinerja BAZIS dalam mengelola dana zakat, diantaranya ada faktor eksternal dan internal:

a. Kondisi Eksternal

1) Masih kurangnya kesadaran pegawai dalam melaksanakan kewajiban berzakat melalui BAZIS

2) Kepercayaan pegawai untuk menyalurkan zakatnya ke BAZIS masih rendah

3) Zakat maal/profesi yang belum terealisasikan secara optimal dikalangan pegawai

4) Belum adanya dukungan maksimal dari Pemda dan DPRD untuk menerbitkan produk hukum yang mendorong pelaksanaan zakat misalnya Perda tentang zakat profesi

b. Kondisi Internal

1) Belum ditemukannya cara efektif menggugah muzakki di lingkungan Pemda unutk menyalurkan zisnya ke BAZIS kab. Bogor

2) Belum terjalinnya koordinasi yang baik antara BAZIS kecamatan dengan BAZIS kab. Bogor

3) Belum memiliki Perda Zakat

4) Sebagian besar pengelola, tidak full time di BAZIS kab. Bogor

5) Belum adanya Standar Operasional dan Prosedur (SOP) keuangan, pendayagunaan, dan pendistribusian yang jelas. ${ }^{38}$

Dengan mengetahui kekurangan dan hambatan yang dihadapi BAZIS diharapkan bisa meningkatkan pengelolaan dana zakat yang dikelola oleh manajemen BAZIS Kabupaten Bogor.

${ }^{38}$ Semua data didapat dari dokumen BAZIS 2008 


\section{Penutup}

Instruksi bupati cukup berdampak atas kesadaran pegawai dalam membayarkan zakat profesi, hal ini dapat diketahui dari angket yang telah dikumpulkan penulis bahwa instruksi bupati cukup berdampak terhadap kesadaran pegawai dalam membayarkan zakat profesi sebagaimana yang telah di instruksikan Bupati dengan sebanyak 74\% dari responden merasakan dampak dari instruksi Bupati dan 10\% lainnya menjawab tidak.

Instruksi bupati juga berdampak dalam peningkatan pegawai yang membayarkan zakat profesi terlihat dari persentasi pegawai yang membayarkan zakat sebelum dan sesudah adanya instruksi. Sebanyak $42 \%$ responden dari pegawai Pemkab menjawab belum membayarkan zakatnya sebelum adanya instruksi Bupati dan 56\% membayarkan zakat profesinya setelah adanya instruksi Bupati. Sedangkan yang lainnya $2 \%$ tidak terpengaruh dengan adanya instruksi itu.

Instruksi Bupati juga cukup berdampak secara tidak langsung terhadap pengelolaan zakat di BAZIS Kabupaten Bogor. Berdasarkan data pendapatan BAZIS dari tahun 2006 sampai degan tahun 2008 terdapat peningkatan yang signifikan. Begitupula dalam pendistribusian dana zakat juga mengalami kenaikan dari tahun sebelumnya.

\section{Acuan Pustaka}

Alquran dan Terjemahan, 2005. Departemen Agama. Penerbit PT Syamil Cipta Media Bandung.

A.Hasan Bulughul Maram Kitabuz Zakat, Diponegoro, Babdung, 1996.

Data dan Dokumen BAZIS Pemda Kab Bogor 2008.

Hafidhuddin, Didin, Zakat Dalam Perekonomian Modern, Gema Insani, Jakarta, 2002.

Hafidhuddin, Didin, Rekaman Tentang Zakat, Risalah Zakat, Jakarta, 2006.

Hafidhuddin, Didin, Panduan Praktis Tentang Zakat Infak Sedekah, Gema Insani, Jakarta, 1998.

Halim, Abdul, Mengapa Zakat disyariatkan, MS2, Bandung, 2001

Hilmi. Menanti kiprah pemerintah Terhadap Zakat, www.pesantrenvirtual.com 
Hawwa, Sa'id, Al-Islam,Al-I'tishom. Jakarta 2001

Idris, Sofwan, Telaah Khusus Zakat Profesi, Risalah Zakat, Jakarta, 2006.

Ibnu Daqiqil, An-Nawawi, Syarah Hadist Arba'in An-Nawawi, 'Arofah, Solo. 2007.

Juwaini, Ahmad, Membangun Peradapan Zakat, Institut Manajemen Zakat, Jakarta 2007.

Muhammad, Abdul Aziz, Fiqih Ibadah, Pustaka Amzah, Jakarta 2009.

Rasjid H. Sulaiman, Figh Islam, Sinar Baru, Bandung, 2000.

Qardhawi, Yusuf. Hukum Zakat, Litera antarNusa, Jakarta, 2004.

Qadir, Abdurrahman, Zakat dalam dimensi mahdhah dan sosial, Grafindo Persada, Jakarta,1998.

Kompilasi Hukum Islam UU Republik Indonesia Tentang Zakat

Yasin Ibrahim, Al-Syaikh, Zakat Penyempurna Puasa dan Membersihkan Harta, Marja, Bandung, 2004.

Majalah Gerimis, edisi 6 thn 4 juni 2009

Shahih Muslim, Kitabul Iman waz Zakah, Darussalam Riyadh,1998. hadist 124.

Muhyiddin, 'Abdul Hamid Muhammad, Sunan Abu Daud, Maktabah Dahlan, kitab zakat. 